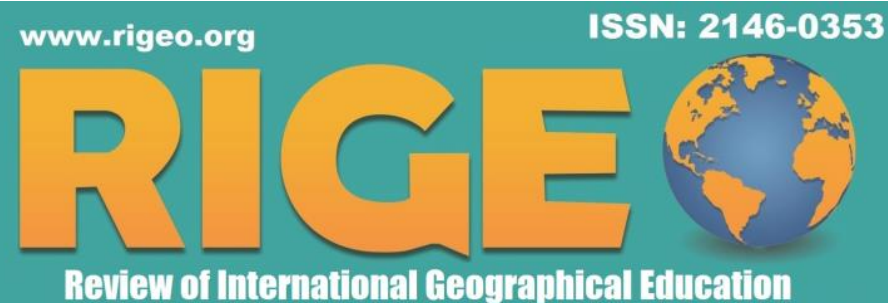

CRIGEO, Volume 10, Issue 1 (Special Issue), 2020

To cite this article: Avcı, G.; Gümüş, N. (2020). The Effect of Outdoor Education on the Achievement and Recall Levels of Primary School Students in Social Studies Course. Review of International Geographical Education (RIGEO), 10, (1), Special Issue, 171-206. Retrieved from http://www.rigeo.org/vol10no1/Number1Spring/RIGEO-V10-N1-9.pdf

\title{
The Effect of Outdoor Education on the Achievement and Recall Levels of Primary School Students in Social Studies Course*
}

\author{
Görkem AVCI ${ }^{1}$ \\ Bartın University, Bartın, TURKEY \\ Nevzat GÜMÜŞ² \\ Dokuz Eylül University, İzmir, TURKEY
}

\begin{abstract}
The aim of this study is to determine the effects of the implementation of activities based on outdoor education in social studies teaching on students' academic achievement and their level of knowledge recall. In the study, semi-experimental design with pretest-posttest control group was used. The study was conducted with the study group determined by selecting the appropriate sample. The study group for the 2018-2019 academic year was composed of two primary school fourth grade students, one from a public school $(\mathrm{n}=33)$ and one from a control group $(\mathrm{n}=31)$ in Buca district of İzmir province. During the application process, fourth grade social studies lesson "People, Places and Environments" learning area subjects were covered for 6 weeks with outdoor education activities and outdoor teaching method, social studies lesson curriculum content and activities in control group. As a data collection tool, the "Academic Achievement Test" created by the researcher within the scope of the primary school fourth grade "People, Places and circles" learning area attainments was used as pre-implementation and postimplementation. In addition, the Academic Achievement Test was used as a persistence test to measure students' level of recall of their knowledge 4 weeks after applications were finished. Statistical solutions of the data were made with descriptive statistics, $t$-test for independent samples, and twofactor ANOVA for mixed measurements. According to the findings, academic success and retention levels of the experiment group students who took outdoor education activities and outdoor education social studies courses were significantly higher than those of the control group students who performed
\end{abstract}

${ }^{*}$ A portion of this research was presented in 2. International Congress on Geographical Education (UCEK/ICGE-2019), 3-5 October 2019, Eskişehir-Turkey.

${ }^{1}$ Corresponding author: Research Assistant Dr., Bartın University, Faculty of Education, Department of Turkish and Social Sciences Education, Bartın, Turkey, E- mail: gorkem.avci.35 [at] gmail.com ORCID: 0000-0002-4489-1613

${ }^{2}$ Prof.Dr., Dokuz Eylul University, Faculty of Education, Department of Turkish and Social Sciences Education, İzmir, Turkey, E-mail: nevzat.gumus [at] gmail.com ORCID: 0000-0003-4144-9990 
courses according to the curriculum and activities of social studies courses in the classroom environment. As a result, it was determined that the implementation of outdoor educational activities in the teaching of social studies courses increased the success levels of the students and positively affected their level of recall their knowledge.

\section{Keywords}

Outdoor Education, Outdoor School Teaching, Outdoor Teaching Method, Outdoor Social Studies Education, Outdoor Learning Environments

Social studies, past, present and future in the context of the child's immediate environment, starting from the world, even extending to the universe and the world to understand the connection and functioning of the aims to complete social development by adapting to the environment in which it is located (Meydan, 2015). The social studies course, which is supposed to take place in the real world and social life itself, is confined to classes in a manner contrary to its nature. No doubt, there are many problems with social studies teaching today, but the first of these problems is that teachers and students are often dependent and limited on the textbook. Students are confined to programs, subjects and content that are free from social experiences, alienated from real life and disconnected from the dynamic community life that exists outdoor the classroom (Foran, 2008). Naturally, no matter what area, discipline, course, subject and content the teaching is confined within the classroom walls, the student is in a passive receptive position and teachers use traditional methods in the teaching process has become one of the most important problems of education. These problems reduce the quality of education and also cause the information learned by the student to be forgotten in a short time (Çerkez, 2011).

The educational concern about social studies is that teaching as a discipline involves only cognitive attainments, rather than being vital, and is seen as an inadequate learning experience for students, stuck to technological tools and confined to interiors. Social studies teaching requires a combination of real experiences and knowledge within an effective curriculum. But the teaching of social studies in today's schools has become an educational process that takes place entirely in the classroom and moves away from society (Foran, 2008). It is better for students to learn the knowledge they have acquired by doing and living, rather than theoretical, real-life and abstract information. "I heard and forgot, I saw and I remember, I do and I understand." The word (Confucius) effectively describes this situation. In order to achieve this situation, it is necessary to leave students with first-hand experiences in a learning environment where they feel free, willing, and comfortable and open to learning (Karakuş, 2006).

Students need to learn directly within the community, associating knowledge, skills and values with real life. The activities to be carried out in this context serve as the basic building block for an effective teaching of social studies (Foran, 2008). When the attainments in the Social Sciences Curriculum (SSC) are examined, it is seen that nearly all of the attainments are related to society and nature, that is, to the outdoor of the classroom. In this context, a lesson that is intertwined with the classroom cannot be expected to be conducted effectively and efficiently in a confined environment with classroom walls. For this reason, outdoor education should be seen as a necessity, not an 
alternative, and should be employed with good planning in education. (Selanik Ay, 2016).

In addition to educating individuals who are aware of the nature consciousness and the environment they live in, approaches that are based on the idea that learning is not limited only to classroom or school walls, but covers the whole of human life, which allow the knowledge attainmented to be used in daily life are taken into consideration. (Ministry of National Education [MoNE], 2017). Despite these approaches, the current situation is slightly different. It is a well-known fact that students are psychologically and physically restricted within the school and thus move away from the real life that is going on outdoor the school. While students try to memorize and remember the information presented to them, they remain disconnected and unfamiliar with real life. The solution to this situation is for the student to make connections and interact with the community in which he or she lives. Therefore, the realization of the aim of education to bring individuals to life will be possible by the participation of students in real life, making observations and investigations, being in different places and interacting with the society in which they live. At this point, the social studies course has the appropriate structure and rich content for the realization of the intended purpose. Thus, in social studies courses, students should be aware of the place and environment they live in, observe the developments, know the history of their families and know the place they live in the local context (Özür, 2010).

It is thought that an understanding of teaching, in which the student takes an active role in the learning process, learns by doing, living, firsthand and the knowledge learned is permanent, is the most effective method in education. One of the approaches in which this understanding comes to life is the "outdoor education" method, which argues that knowledge must be learned through first-hand observation and experience outside the classroom in order to enrich, enliven and complete the curriculum (Eaton, 1998). In its most comprehensive form, although it has many definitions, outdoor education is defined as education done about and for the purpose of outdoor education (Donaldson ve Donaldson, 1958). By this definition, where learning will take place (outdoor learning environments), subject-content to be taught (issues related to nature and the environment), and the purpose of the activity are literally stated (Ford, 1986). According to the Institute for Outdoor Learning, outdoor education, defined as purposeful and planned outdoor experiences (Prince, 2018), does not mean a school trip, school yard or outdoor course. Outdoor education covers a very rich and wide area, from school gardens to an industrial place, from marshes to meadows, forests, shores, lakes, museums to zoos and botanical gardens, parks to natural environments, and tripsobservation studies and visits with scientific content (Ford, 1986). Outdoor education is an education that enables the realization of teaching activities in a planned and programmatic way and supports-improves formal education (Şimşek ve Kaymakçı, 2015). In this aspect, it departs from informal education (Kan, 2018), which is unplanned, unscheduled, does not require a specific space or learning environment, has no specific goals, is self-realized, has no institutional and systematic structure. 
In the early years when the foundations of outdoor education were laid, a variety of explanatory and classificatory information was put forward. However, priest's "outdoor education tree" is often used as it forms the first Systematics in the fieldwork (Figure 1).

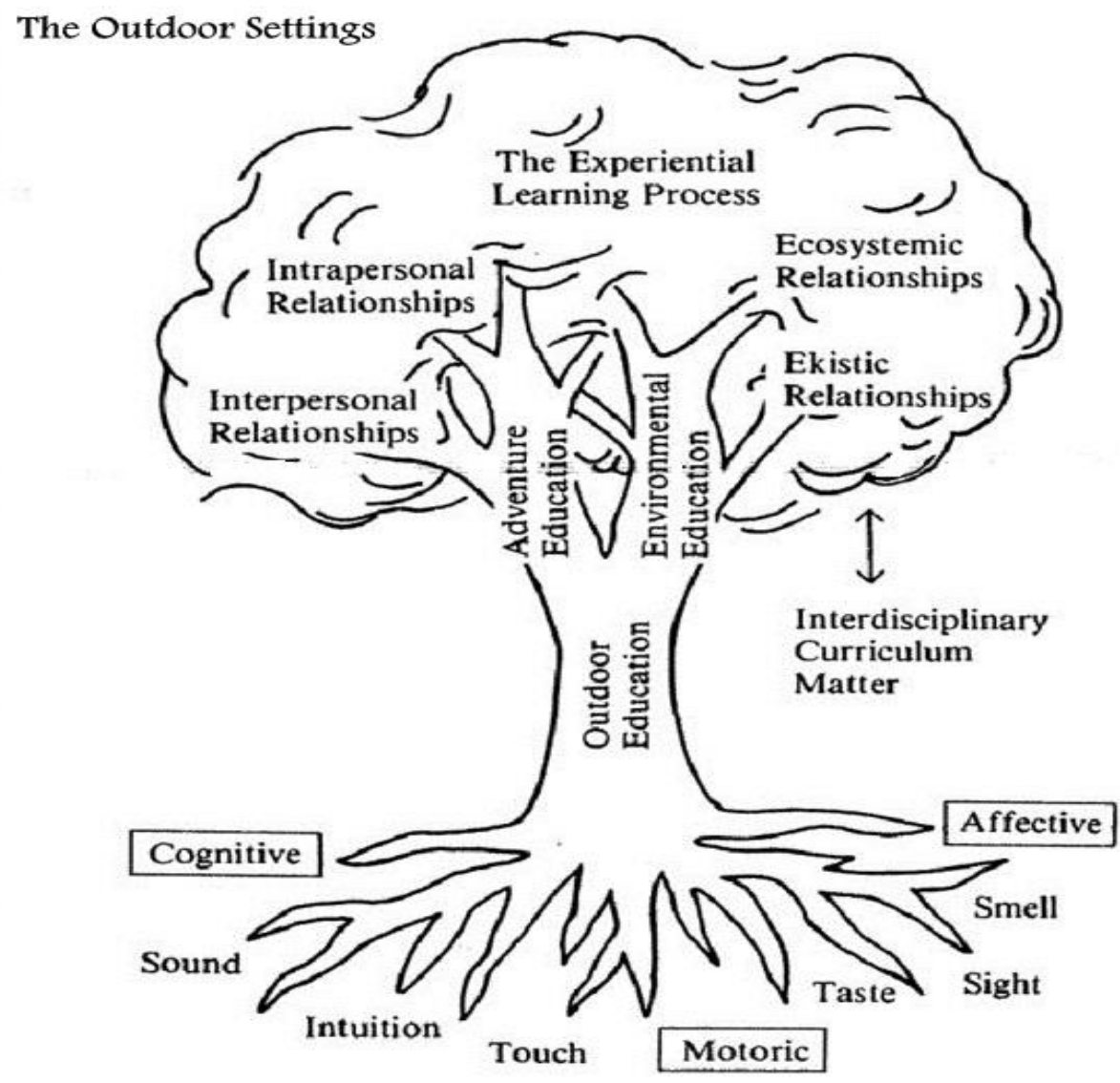

Figure 1. Outdoor education tree (Priest, 1986)

As can be seen in the outdoor education tree (Figure 1), it is seen that outdoor education is an experience-based learning process in which many multifaceted senses (6 senses) are used, it contains processes covering cognitive, affective and dynamic areas, it covers nature-human, human-society and human relations, it is divided into two areas such as environment and adventure education (Priest, 1986). In the early years of its configuration, outdoor education was divided into two branches, "adventure education" and "environmental education" (Priest, 1986), and later "outdoor activities" were included in this classification (Priest, 1988). Environmental education is the type of education that involves the whole environment, including population growth, pollution, use and poor use of resources, urban and Rural Planning, and Natural Resources and modern technology (Ford, 1986). Adventure training is the training process in which all persons involved in direct, active and learning experiences and actual results are included (Prouty, Panicucci ve Collinson, 2007). In a different classification, "placebased education", "experiential education" and "outdoor education"are given under the same title as pedagogical structures that use the environment (Edlund, 2011). Placebased education, language education, the arts, mathematics, social studies, science and 
other curriculum subjects in the teaching of knowledge and concepts as a starting point for the process of using the environment and the local community is defined as (Sobel, 2004). Experiential Education is the process of active participation between the inner world of man and the outer world of the environment. This process involves a holistic approach involving thoughts, emotions and physical activity (Beard ve Wilson, 2006).

Outdoor education is an experiential process that takes place outdoor the classroom, based on learning by doing-living (Priest, 1986). In another definition, outdoor education is a process involving direct learning experiences, or a method of teaching that reinforces and supports teaching (Ford, 1986). As can be seen from the explanations, it is a problem to classify outdoor education clearly, clearly and clearly and to show it under a certain heading. This problem stems from the complex use of concepts, terms and ideas in an international dimension (Jirásek, Plevová, Jirásková ve Dvořáčková, 2016). In addition, this confusion is caused by the close and almost similar activities carried out within the scope of these concepts.

A new method of learning within Formal education, outdoor education (Gilbertson, Bates, Ewert and McLaughlin, 2006), has its philosophical foundations laid by thinkers such as Rousseau, Pestallozi, Comenius and Dewey (Mcgowan, 2015). When outdoor education was first introduced in the 1920s, the concept of camp training and scouting came to the fore in its definition (Caner, 2009). The first outdoor training camp was education in 1861 by Gunn (Gilbertson et al., 2006).) And then many education took place and continued in many countries up to the present day. It is thought that outdoor education practices began in Broadoaks schools in the United States. The idea of using nature as a laboratory in teaching was included in the teaching program of the school and for the first time, outdoor education was included in the primary education program (According to Stine, Okur Berberoğlu and Uygun, 2013). Since the publication of Richard Louv's groundbreaking book "The Last Child in Nature" in 2005, a worldwide movement linking young people and nature has begun, and its reflection on education has not been delayed (Caner, 2009). Today, outside of the classroom education in the international dimension; Institute (the Institute for Outdoor Learning), faculty-partprogramme (Linköping University), Councils, units (English Outdoor Council) operates the course (GMIT Outdoor education courses, educational training programs (course for teachers outdoor education-Outdoor Education: a new way of teaching and learning), symposium and conferences conducted (The Outdoor Education Conference), projects (Outdoor Classroom Project, Dirt is good) is carried out, and also schools (Beaufort primary school) and training centers (Cappanalea outdoor education Centre Seguin Outdoor Learning Center, Colorado Outdoor Education Center) continue their education activities with this approach. In addition, outdoor education instructor is in demand for outdoor Activities (high Quality Outdoor Education, 2005; high Quality Outdoor Learning, 2015) is published, and outdoor education activities are tried to be carried out effectively by setting up learning environments (Thornhill Outdoor Education Campus).

In our country, non-classroom education began with the teaching of hunting and martial arts during the period when the Turks were nomadic, and continued in the Ottoman state for the same purpose. The ahiq organization has made progress with its activities and has been implemented with the programs of village teacher schools and 
village ensembles. For twenty years, the Scientific and Technological Research Council of Turkey (TÜBİTAK) has been supporting outdoor education projects (outdoor nature education and science camps), so that outdoor education practices continue (Okur Berberoğlu and Uygun, 2013). In our country, many schools and organizations whose basic philosophy is outdoor education and which carry out their activities in this direction also play an important role in the development of this approach. "new school" kids in the woods-by-learn by doing and experiencing, not just classes, the garden, the library, the workshops, designed as a learning environment in the hallway of the school, the courses of art workshops are supported with a school. Another of these schools, "let them go out", "no walls, no classrooms", "everything we need in the open air" adopted the slogans "forest school", the individual by doing and living with regular stimuli to participate in the education process and in doing this, the natural environment is also involved in this process is implemented a cross-program. In addition, the "I learn in Nature" School, whose aim is to spread the education given on pedagogical basis in nature, despite all weather conditions, in every season, aims to create a turkey in which the child, teacher and parent connect with nature without harming nature and supports the spread of outdoor class education in our country. "Outdoor Clasroom day", where there is high participation from all countries of the world and active participation from Turkey, continues to raise awareness about outdoor education for students, schools and participants in our country. Finally, in addition to the ongoing work, the MoNE has taken up outdoor education within the scope of the 2023 Education Vision and has taken action to start applications as of the 2019-2020 academic year (MoNE, 2019). All these studies have contributed significantly to the development of non-classroom education in our country. According to Dewey, the strangest and worst part of today's schools is that they aim to prepare students for social life in a space completely free from reality to the conditions of social life (According to Kanad, Tokcan, 2015). The fact that students are passive in the classroom is contrary to both their nature and their needs. Dewey has cited schools as places that give children not just information, but places that give them the ability to think to find their way in real life. The greatest danger to the school is that it is transformed into an artificial environment independent of the conditions and problems of the environment and the place being lived. Instead of having the student memorize the information in the school, the student should be confronted with real life. The way to do this is to take the teaching out of the classroom and meet with the real life. For this reason, Dewey is seen as the most important educator with an emphasis on the importance of outdoor education (Tokcan, 2015).

"Dirt is good/it is good to be dirty" in addition to the non-classroom education activities that continue decisively in our country and in the world. The research carried out under the "campaign" (Unilever, 2016) points to a crucial point that proves the importance of outdoor education: "today's children spend less time outdoors than inmate in a highly sheltered prison in America" (Prisk and Cusworth, 2018, according to Edelman". As mentioned here, almost half of the world's people connected to the internet and also as with any online social media tool that some of this sector is living in a digital age (Echazarra, 2018). To play the online game a socio-economic indicator (OECD, 2017), to obtain the companionship and sustaining online relationships 
(UNICEF, 2017), the young people they sacrificed their sleep for texting (Pew Research Center, 2018), the internet and social networks in order to afford to move away from eating disorders (Holland and Niggemann, 2016) when they get excited when they discover a new digital tool or application, the internet connection broke when they are feeling sad, they forgot about the time when dealing with technological tools (OECD, 2017) a century, it exposes young people to living indoors and between walls for a long timeMost countries continue to take measures to reduce the dependence on technology and the internet, which have many negative effects and are seen as indispensable in today's world. Accordingly, initiatives are underway in many countries such as the United States, South Korea, Germany, Japan, United Kingdom (Korean Internet \& Security Agency-KISA), online activities in Germany, trainings are held, rehabilitation camps are held (OECD, 2018). Parents, researchers and especially teachers have important tasks to do to ensure that children are not affected by the risks of the digital world. It has been recognized by researchers that while the time spent outdoors in order for children to live a healthy life varies, it is a need or even a necessity for children (Edwards, 2019; Ginny, 2019; Harveston, 2019; Kirkpatrick, 2019; Loria, 2018). Also; the results of this study showed that connecting with outdoor by doing-living in outdoor learning environments improves children's ability to focus, improves their selfconfidence, reduces stress, contributes to coping with depression, improves mental health and general health (well-being) (Maller, 2009).

The outdoor teaching method, which advocates the realization of education where it can be done and where its purpose can be achieved, covers activities at elementary school, middle school, high school, university level and in many geographical settings (Ford, 1986). No matter what subject or content is processed, activities must be carried out either by going to the real environment or the class must be transformed into an environment to enable these activities to take place. Since it is very difficult to design and put the classroom environment in such a way as to represent real life, real life must be seen outside the classroom and faced with life. Therefore, constructivist education is an approach based on outdoor learning (Tokcan, 2015). Today, urban life, digital world, technological tools and social media have placed students under house and school confinement. Fourth grade primary school in San Diego. "I like playing at home more because all the electrical appliances are there" his testimony proves this case (Louv, 2018). Families, and especially educators, have a great role to play in overcoming these addictions. What educators must undertake is to increase the quality and function of school gardens, which are a learning-teaching environment, to enable students to spend at least part of their time outdoors the classroom, albeit for a short time during school hours. In this context, the social studies course offers unique learning environments, materials and many opportunities for outdoor education and training activities. Due to the appropriateness of the basic philosophy and structure of the social studies course content, it is important to adopt it in social studies courses in order to achieve the effective goal of outdoor education. Outdoor learning environments can help students communicate with their peers, understand others, work together democratically and towards common goals, develop community awareness and understand their own place in the world. Accordingly, "understanding the real world is possible with the realization 
of learning in $99 \%$ of human existence. But people have trapped the work of learning inside a small box called a classroom for a century."The statement points out that education should not remain in the classroom (Hodge, 2004: 36, according to by Lieberman). In this respect, outdoor learning environments and learning in these environments are important for many courses and social studies courses. When the field is examined, the studies are concentrated in the field of science (Aslan and Demircioğlu, 2018; Bakioğlu, 2017; Saraç, 2017). In the dimension of social studies education, outdoor teaching method and outdoor educational activities have often been the subject. Studies in this direction have been more frequent, especially in the United States and European countries. In our country, the importance of sightseeing and observation studies has been emphasized, but there have been no extensive studies developed from a general point of view (Özür, 2010). International studies have been conducted in different countries. Thus, the current status of the outdoor teaching method has been determined on a global scale. In international studies related to outdoor educational activities and teaching method, there is clearly no concept unity, and outdoor education is defined and classified in different ways (adventure education, environmental education, school-based outdoor class experimental education, nature education, etc.) seen (Smith and Walsh, 2018 ).

It is stated that outdoor education has become systematic in the modern sense in the world (Yazıcı ve Çobanoğlu, 2017). It is stated that there is orientation towards outdoor education both in the world and in our country (Bakioğlu, 2017; Cirit Gül, Tağrikulu and Çobanoğlu, 2018) and it continues to develop as a field of study in this direction (Sözer and Oral, 2016). It is possible to group studies in domestic and international literature as opinion, theoretical and application-based studies. Theoretical studies in Turkey and in the world about "out-door education" includes historical development, promotional studies and studies related to philosophical foundations. Application-based studies are evaluated in terms of the success, skill development and change in attitudes of the students. In addition, the majority of the studies consist of the activities in which the teacher, student, parent and school administration also participate and interviews about experiences are obtained.

The research was inspired by the idea of revealing the importance of activities based on outdoor class teaching in order to contribute to the level of remembrance and to assimilate the knowledge thoroughly. Furthermore, in determining the purpose of the research, the idea that the outdoor activities focused on the realization of the social studies course in the curriculum were ignored in the teaching process and that social studies teaching should be realized by firsthand observations, studies and living by doing. In this context, the main objective of the research is to determine the effects of outdoor educational activities in social studies teaching on the academic success of the students and their level of remembering their knowledge.

The social studies course, which has a wide range of content, allows the student to adapt to the society in which he or she lives, while making it necessary for the students to be removed from the classroom walls during the course. Outdoor learning environments for teaching social studies contain very rich resources (Foran, 2008). The schoolyard, a vacant area around the school, a Land, park, Street serves as a laboratory 
for learning and observation by living by doing from the point of view of the students. In this context, education and training activities were carried out in the school yard, near the School (street, park, empty area), land (forest, lake, bridge), public institutions (Meteorological Station, Disaster and Emergency Department [AFAD]), rural (village) and urban (city center) areas. This research is important in terms of the impact of activities applied in different learning environments within the scope of outdoor education in social studies on students' academic achievement and their level of awareness. The literature type is examined, earlier studies of general environmental education, nature education, school trips (museums, zoo, historical places, nature and a trip to...), the school's playground activities, or informal learning environments to gain awareness of environmental protection and ecological balance were within the scope of trips that occurred in education. In addition, it has been determined that classroomoutdoor learning studies are concentrated in the literature of science (Bakioğlu, 2017) and theoretical studies are conducted at the level of social studies education. Therefore, there was no study in which the social studies course teaching was carried out with a comprehensive outdoor educational activities that took place in many different learning environments by adopting an "outdoor course processing" approach and the results of which were evaluated with strong and rich data in the context of academic success and persistence. These findings and the objectives adopted for the identified deficiencies make this study different from other studies. The study is considered to be valuable in terms of demonstrating the importance of outdoor education in teaching social studies courses, to give teachers ideas and to contribute to students. Depending on the determined research purpose, answers to the following research questions were sought:

1. Test and control group "Academic Achievement Test" is there a significant difference between pre-test and post-test scores?

2. Is there a significant difference between test and control group "Academic Achievement Test" post-test and recall test scores?

\section{Method}

\section{Research Design}

In the study, a "pretest-posttest control group semi-experimental design" was used from quantitative research methods. Within the framework of this design, the impact of the outdoor teaching method on the students' academic achievements and their level of knowledge were examined in the teaching of the "People, Places and Enviroments" learning area subjects of the elementary school fourth grade social studies course. In this context, it is aimed to test the effect of independent variables (outdoor teaching method and activities-content and activities of SSC) on dependent variables (academic achievement, level of remembrance).

The semi-experimental method is often used in educational research (Çepni, 2014). The use of a quasi-experimental research design is appropriate when the effect of teaching materials or teaching methods on certain variables is investigated (McMillan and Schumacher, 2006). In addition, in the study, semi-experimental design was used instead of actual experimental design because it was not possible to assign students to 
random groups and it was necessary to work with existing groups (Çepni, 2014). The "pretest-posttest control group experimental design" is a strong research design. However, there is a risk of a decrease in the sensitivity of the participants due to the application of the measurement instruments twice to the groups. For this reason, monitoring is suggested at a certain time after the end of experimental practice (Heppner, Kivlighan and Wampold, 1999). Therefore, 4 weeks after the end of the experimental practice, monitoring was carried out (recall test) to determine whether the effect of the experimental process (outdoor teaching methods and activities) continued. The representation of the pattern in the research is shown in Table 1.

Table 1

Symbolic view of the research model

\begin{tabular}{|c|c|c|c|c|}
\hline Group & Pre-test & Period & Post-test & Recall Test \\
\hline & \multirow{3}{*}{$\begin{array}{c}\text { - Academic } \\
\text { Achievement } \\
\text { Test }\end{array}$} & -Outdoor teaching & \multirow{3}{*}{$\begin{array}{c}\text {-Academic } \\
\text { Achievement } \\
\text { Test }\end{array}$} & \multirow{3}{*}{$\begin{array}{c}\text {-Academic } \\
\text { Achievemen } \\
\text { Test }\end{array}$} \\
\hline Experiment & & $\begin{array}{l}\text { Methods and } \\
\text { Activities }\end{array}$ & & \\
\hline Control & & $\begin{array}{c}\text {-Social Studies } \\
\text { Curriculum and } \\
\text { Activities }\end{array}$ & & \\
\hline
\end{tabular}

As shown in table 1, there is an experiment and control group in the research. In the study, outdoor educational activities and outdoor teaching method were applied. In the control group, SSC and its activities were implemented.

\section{Working Group}

Since the pattern of the study was a semi-experimental study, the appropriate sample selection was preferred and the application of the study was conducted with the determined working group. In experimental research, it should be considered that experiment and control groups should be as equivalent groups as possible during the formation of groups (Çepni, 2014). By looking at some data, the researcher should select the two most similar groups (Büyüköztürk, Çakmak, Akgün, Karadeniz and Demirel, 2018). Since an experiment and a control group were needed in the research, the equivalence states of the classes were looked at first. In this context, psycho-social characteristics and socio-economic level (Personal Data Form), academic achievement test (AAT) and teacher opinions were used to determine the equivalence of groups. In order to conduct the research in equal groups in terms of success level, academic achievement test was used in fifth grade (4/A, 4/B, 4/D, 4/F, 4/g) together with personal data form and the $4 \mathrm{~B}(\overline{\mathrm{x}}=11.48)$ and $4 \mathrm{G}(\overline{\mathrm{x}}=11.41)$ classes with the closest average scores were included in the study. In both groups, the T-test was performed for unrelated samples to determine whether the social studies course academic achievement prediction scores differed and the results of the analysis were shown in table 2. 
Table 2

T-test results according to academic achievement test score averages of experiment and control groups

\begin{tabular}{lllllll}
\hline Group & $\mathbf{N}$ & $\overline{\mathbf{x}}$ & $\mathbf{S}$ & $\mathbf{s d}$ & $\mathbf{t}$ & $\mathbf{p}$ \\
\hline $4-\mathrm{B}$ & 33 & 11.48 & 2.94 & \multirow{2}{*}{62} & \multirow{2}{*}{095} & .925 \\
$4-\mathrm{G}$ & 31 & 11.41 & 2.56 & & & \\
\hline
\end{tabular}

When table 2 was examined, it was observed that there was no statistically significant difference between the success test scores of the groups [ $t(62)=.095, \mathrm{p}>.05]$. In line with these results, it is possible to say that the readiness levels of the experiment and control group were approximately the same level. In addition to being close to each other in terms of psycho-social and socio-economic variables, it was concluded that equivalence states were close to each other in terms of teacher opinions and personal data form data. As a result of this equalization process, the classes were determined as experiment and control groups by drawing lots. The experiment group determined as a result of the assignment consists of 33 students and the control group consists of 31 students. The personal information of the students involved in the study is shown in Table 3.

Table 3

Frequency $(f)$ and percentage (\%) distributions of the personal information of the students in the experiment group and control group

\begin{tabular}{|c|c|c|c|c|c|}
\hline \multirow{2}{*}{ Variables } & & \multicolumn{2}{|c|}{ Experiment Group } & \multicolumn{2}{|c|}{ Control Group } \\
\hline & & $\mathbf{N}$ & $\%$ & $\mathbf{N}$ & $\%$ \\
\hline \multirow{2}{*}{ Gender } & Female & 15 & 45 & 16 & 52 \\
\hline & Male & 18 & 54 & 15 & 48 \\
\hline \multirow{3}{*}{ Income Classes } & Low & 2 & 6 & - & - \\
\hline & Medium & 23 & 70 & 25 & 81 \\
\hline & High & 8 & 24 & 6 & 19 \\
\hline \multirow{5}{*}{$\begin{array}{l}\text { Maternal } \\
\text { Education Status }\end{array}$} & Primary & 5 & 15 & 7 & 23 \\
\hline & Secondary & 1 & 3 & 4 & 13 \\
\hline & High School & 16 & 48 & 12 & 39 \\
\hline & Undergraduate & 10 & 30 & 8 & 26 \\
\hline & Graduate & 1 & 3 & - & - \\
\hline \multirow{5}{*}{$\begin{array}{l}\text { Paternal } \\
\text { Education Status }\end{array}$} & Primary & 4 & 12 & 6 & 19 \\
\hline & Secondary & 1 & 3 & 4 & 13 \\
\hline & High School & 8 & 24 & 12 & 39 \\
\hline & Undergraduate & 19 & 58 & 9 & 29 \\
\hline & Graduate & 1 & 3 & - & - \\
\hline \multirow{2}{*}{$\begin{array}{l}\text { Taking Private } \\
\text { Lessons }\end{array}$} & Yes & 6 & 18 & 1 & 3 \\
\hline & No & 27 & 82 & 30 & 97 \\
\hline \multirow{2}{*}{$\begin{array}{l}\text { Computer Inside } \\
\text { the House }\end{array}$} & Yes & 25 & 76 & 24 & 77 \\
\hline & $\mathrm{No}$ & 8 & 24 & 7 & 23 \\
\hline \multirow{2}{*}{ Internet } & Yes & 25 & 76 & 21 & 68 \\
\hline & No & 8 & 24 & 10 & 32 \\
\hline
\end{tabular}




\begin{tabular}{llllll}
\hline \multirow{3}{*}{$\begin{array}{l}\text { Age Level of } \\
\text { Book Reading }\end{array}$} & $1-5$ age & 4 & 12 & 3 & 10 \\
\cline { 2 - 6 } & $6-10$ age & 2 & 6 & 4 & 13 \\
\cline { 2 - 6 } & $16-20$ & 3 & 9 & 8 & 26 \\
\cline { 2 - 6 } & $21+$ & 24 & 73 & 16 & 52 \\
\hline \multirow{2}{*}{$\begin{array}{l}\text { The Access Way } \\
\text { to Information }\end{array}$} & Books in the House & 12 & 36 & 12 & 39 \\
\cline { 2 - 6 } & Internet & 19 & 58 & 17 & 55 \\
\cline { 2 - 6 } & Other Libraries & 2 & 6 & 2 & 6 \\
\hline
\end{tabular}

As can be seen in table 3 , students in study groups have similarities in terms of gender, parents' educational status, having computers and internet in their homes, the number of books they have and the way to access information.

Educational activities and teaching methods outdoor the classroom with a group of students in the study (experiment group) with the SSC and its activities with the learners group (control group) academic achievement, and information supports that there is a significant difference between the levels of remembering. In this context, the students who studied with outdoor teaching methods and activities formed the experiment group, while the students who studied with social sciences curriculum content and activities formed the control group. Teaching methods and activities outdoor the classroom the lessons in the experiment group processed with the control group, any intervention, not mostly the lessons in the classroom lecture, discussion, question-answer method and techniques was conducted.

\section{Data Collection Tools}

Data were collected before and after experimental practice. Prelims before the application and post-tests after the application were applied. Furthermore, the data collection process was completed by applying persistence tests 4 weeks after the application of post-tests.

To collect data in research;

1. "Personal Information Form" to determine some psycho-social and socioeconomic characteristics of students for use in relation to equivalence states of groups,

2. People, places and environments learning area "Academic Achievement Test" in order to determine the academic achievement level of the students before and after the experimental process and to determine the level of remembering the information of the students 4 weeks after the end of the experimental process.

Personal information form. In order to determine some psycho-social and socioeconomic characteristics of the students in the working group, 9-item "A Personal Information Form" has been created. In the form of personal information used to identify and equalize working groups, gender of students, average monthly income of their parents, education status of their parents, private lessons, whether they have a computer and internet connection at home, the auxiliary resource they use (books, question banks, journals, etc.) number, information about the ways to access information is included. 
Academic achievement test. The "Academic Achievement Test (AAT)" which is used as a pre-test, post-test and persistence test to cover the gains in the learning area of the fourth grade social studies course "people, places and environments" has been developed by the researcher. AAT was applied to the test and control group as a pre-test before application, post-test after application and as a persistence test 4 weeks after application.

The AAT used in the research was created while primary school 4. grade the in the literature of "people, places and environments" learning were taken into account in the class SSC and the statement table was prepared. In order to ensure the validity of the scope of the AAT, expert opinions were taken from different branches of science about whether the questions were qualified to measure the desired behavior, their relevance in terms of meaning, scope and grade level, the suitability of the detractors and the correct answer to the questions, the accuracy of the contents in scientific terms, the technical. In addition, errors regarding spelling and spelling rules have been corrected in line with the language expert's opinions.

Preliminary application of the test prepared Buca Meşkure Şamlı Secondary School and Buca Saadet Emir Secondary School in İzmir it was applied to a total of 285 students who were in its 5 . grades. The correct answers given by the students are 1 , wrong and null ones are 0 and the substances in the test are analyzed. Then, the substance analysis and reliability coefficient were determined and statistically insufficient substances were removed from the test. After the preliminary application was completed, the reliability coefficient and substance analysis of the test were calculated using TAP (Test Analysis Program). The first version of the test was prepared to include a total of 42 questions, with 7 questions per win. After the reliability application, 21 substances with low substance difficulty and distinctiveness index were excluded from the test. Preliminary application of the test prepared Buca Meşkure Şamlı Secondary School and Buca Saadet Emir Secondary School in İzmir it was applied to a total of 285 students who were in its 5 grades. The correct answers given by the students are 1, wrong and null ones are 0 and the substances in the test are analyzed. Then, the substance analysis and reliability coefficient were determined and statistically insufficient substances were removed from the test. After the preliminary application was completed, the reliability coefficient and substance analysis of the test were calculated using TAP (Test Analysis Program). The first version of the test was prepared to include a total of 42 questions, with 7 questions per win. After the reliability application, 21 substances with low substance difficulty and distinctiveness index were excluded from the test.

Substance difficulty (Büyüköztürk et al., 2018) with values between 0.36 and 0.88 , and the average substance hassle index is 0.65 . Substance differentiation, which shows the degree to which substances distinguish individuals in relation to the measured particular (Büyüköztürk et al., 2018) is between 0.31 and 0.54 with an average substance Differentiability index of 0.43 . The kr-20 value was calculated and the Kuder Richardson reliability coefficient was found to be 0.74 . Calculated reliability coefficient .70 and higher is considered sufficient for the data collection tool to be used in research (Büyüköztürk, 2017). As a result, the analysis to develop AAT showed that the test was 
reliable (KR20: 0.742), that it was a test with an average difficulty (mean substance difficulty: 0.654) and that its distinctiveness was very good (mean substance discrimination: 0.433$)$.

\section{Implementation Process}

The research was conducted in two grades, one experiment and one control group. The duration of the experimental study was limited to 6 weeks and the application was carried out during the fall semester of the 2018-2019 school year. The courses were handled by the teachers in order not to affect the students ' readiness levels in the experiment and control groups. No intervention was made in the control group and only information about the process and control group was received from the teacher. During the experimental applications, the courses of the experiment group were carried out according to the lesson plans created based on outdoor education, while in the control group the courses were carried out without any changes to the lesson plan being implemented.

The activities of the students in the study group are planned within the scope of the social sciences curriculum "people, places and environments" learning area gains. The activities are prepared to cover the outdoor of the classroom as a medium and no changes or additions have been made regarding the subjects, content and achievements in the social studies teaching program. The reason for this is the idea that the subjects of "people, places and environments" learning area, which constitute the main idea of research, should be "taught by doing, living, studying and observing outdoor the classroom".

\section{Preparation of Research Activities}

During the preparation of the Activities, both publications and programs related to the subject were examined and the practices were paid attention. As a result of these investigations, it was decided to configure the activities in this direction based on the "outdoor the classroom" of all activities to be held. 4 after deciding on the approach to be based on teaching. it is predicted that the teaching of "people, places and environments" learning area subjects, which are mainly geography oriented and require human and environmental interaction (MoNE, 2018), will be more effective outside the classroom rather than being carried out with methods and techniques such as lecture and question and answer within the classroom. In this direction, it is decided to teach this learning area outdoor the classroom (MoNE, 2018), which aims to provide students with "spatial knowledge, skills and values" for human life and the continuation of life. The activities reached as a result of the survey of the literature are collected in the activity pool. The activities collected in the activity pool were made to have the structure to represent the "people, places and environments" learning area attainments at the highest level. All of the activities were prepared by the researcher and these activities were organized for İzmir province where the application was made. In the final stage, a classroom teacher, a social studies education and a classroom education specialist were consulted in order to determine the appropriate ones to be used in the application process and to finalize the activity program. 


\section{Research Environment}

In the implementation of the activities prepared, it was aimed that all the environments in which the course is conducted in line with the view based on the teaching should be out of the classroom and certain learning environments were preferred in this direction. Adjustment of research environments, planning, transportation and administrative leave processes (Governor's trail, permissions obtained through oral appointment system and permissions obtained through official institution correspondence through the school of practice) were carried out by the researcher. The type of learning environments in which the course is conducted and the reasons for preference are given in table 4.

Table 4

Environments used in research, type of environments and reasons for preference

\begin{tabular}{|c|c|c|}
\hline Type & Place & Reason of Preferred \\
\hline Training Ares & Schoolyard & $\begin{array}{l}\text { Providing opportunities for educational } \\
\text { games and physical activities when } \\
\text { weather conditions are favorable. }\end{array}$ \\
\hline \multirow{3}{*}{$\begin{array}{l}\text { Parks, Open } \\
\text { Places, } \\
\text { Reclamation } \\
\text { Areas }\end{array}$} & Gen. Vecihi Akın Park & $\begin{array}{l}\text { To be close to the school and to be } \\
\text { suitable for activities. }\end{array}$ \\
\hline & Buca Pond & $\begin{array}{l}\text { It combines natural and human elements } \\
\text { and allows students to see the distinction } \\
\text { between them, and is suitable for } \\
\text { research and exploration. }\end{array}$ \\
\hline & Buca Yedigöller Park & $\begin{array}{l}\text { As a location, Buca is seen from the hill } \\
\text { and is located in a quiet location, } \\
\text { avalanche, flood, landslide, such as the } \\
\text { unlikely to be seen places suitable for } \\
\text { screenings of activities. }\end{array}$ \\
\hline $\begin{array}{l}\text { Village-Rural } \\
\text { Settlement }\end{array}$ & Kaynaklar Village & $\begin{array}{l}\text { Natural habitat, population and } \\
\text { settlement in terms of urban settlements } \\
\text { differ according to the appropriate } \\
\text { observation. }\end{array}$ \\
\hline Open Area & Land & $\begin{array}{l}\text { Natural open place contains many } \\
\text { elements of nature. }\end{array}$ \\
\hline $\begin{array}{l}\text { Nature and } \\
\text { Sports Center }\end{array}$ & $\begin{array}{l}\text { Scouting and Extreme } \\
\text { Sports Center }\end{array}$ & $\begin{array}{l}\text { It contains adventure training, it remains } \\
\text { within the village, it is a safe open place, } \\
\text { it contains many natural and human } \\
\text { elements. }\end{array}$ \\
\hline \multirow{2}{*}{$\begin{array}{l}\text { Official } \\
\text { institutions } \\
\text { and } \\
\text { organizations }\end{array}$} & $\begin{array}{l}\text { The Meteorology } 2 . \\
\text { Regional Directorate }\end{array}$ & $\begin{array}{l}\text { Weather measurements are made and } \\
\text { there are many old-new technical } \\
\text { instruments in the body, there are expert } \\
\text { personnel, suitable for observation.. }\end{array}$ \\
\hline & $\begin{array}{l}\text { İzmir Provincial Disaster } \\
\text { and Emergency } \\
\text { Directorate }\end{array}$ & $\begin{array}{l}\text { The presence of a large training site } \\
\text { showing the damage caused by } \\
\text { earthquakes and disasters, the presence }\end{array}$ \\
\hline
\end{tabular}


of vehicles and equipment not available in many places, the presence of expert personnel related to earthquakes and disasters.

It is a center that provides practical

İzmir Metropolitan

Municipality Fire and

Natural Disaster Center training on disasters such as fire and earthquake, and has a very small number of earthquake house simulators in Turkey.

Close proximity, important addresses

Environment

IZBAN station, Forbes

Street, Mevlana statue,

Şahin Hill, Konak, İnciraltı terms of population and height.

\section{Implementation of Activities}

In the experiment group, the 2018 SSC fourth grade" People, Places and Environments" learning area gains were attempted to be achieved through activities created based on the outdoor teaching method. A six-week experimental application process week in the experiment group according to the topics, issues and activities, time periods allocated to activities, courses, materials, learning environments and activities that occur in table 5 where the information is located.

Table 5

Activity Program

\begin{tabular}{|c|c|c|c|c|}
\hline Issue & Activity & $\begin{array}{l}\text { Instructional } \\
\text { Technologies and } \\
\text { Materials }\end{array}$ & Place & Time \\
\hline \multirow[t]{2}{*}{$\begin{array}{l}\text { 1.Week } \\
\text { Directions }\end{array}$} & $\begin{array}{l}\text { Activity } 1 \\
\text { My } \\
\text { Navigation } \\
\text { Methods }\end{array}$ & $\begin{array}{l}\text { Arrow, wristwatch, } \\
\text { Compass stick, GPS } \\
\text { instrument }\end{array}$ & $\begin{array}{l}\text { Schoolyard, } \\
\text { Park, Buca } \\
\text { Pond, } \\
\text { Graveyard, } \\
\text { House }\end{array}$ & $\begin{array}{l}2 \text { lesson } \\
\text { hours }\end{array}$ \\
\hline & $\begin{array}{l}\text { Activity } 2 \\
\text { I Find My } \\
\text { Target }\end{array}$ & $\begin{array}{l}\text { Neighborhood model, } \\
\text { Target Cards }\end{array}$ & Scoolyard & $\begin{array}{l}1 \text { lesson } \\
\text { hours }\end{array}$ \\
\hline \multirow[b]{2}{*}{$\begin{array}{l}\text { 2.Week } \\
\text { Let's Make } \\
\text { Directions! }\end{array}$} & $\begin{array}{l}\text { Activity } 3 \\
\text { I'm Drawing } \\
\text { a Sketch map }\end{array}$ & $\begin{array}{l}\text { Neighborhood } \\
\text { model,work sheet( I } \\
\text { drawing sketch map), } \\
\text { target cards }\end{array}$ & Schoolyard & $\begin{array}{l}2 \text { lesson } \\
\text { hours }\end{array}$ \\
\hline & $\begin{array}{l}\text { Activity } 4 \\
\text { I Need to } \\
\text { Know the } \\
\text { Safe Places }\end{array}$ & - & $\begin{array}{l}\text { Schoolyard } \\
\text { (emergency } \\
\text { gathering } \\
\text { areas, shelter, } \\
\text { school } \\
\text { emergency }\end{array}$ & $\begin{array}{l}1 ? \\
\text { lesson } \\
\text { hours }\end{array}$ \\
\hline
\end{tabular}


exits and safe

areas) and its

immediate

surroundings

\begin{tabular}{|c|c|c|c|c|}
\hline \multirow{2}{*}{$\begin{array}{l}\text { 3.Week } \\
\text { There is } \\
\text { Going on } \\
\text { Around us? }\end{array}$} & $\begin{array}{l}\text { Activity } 5 \\
\text { Natural? } \\
\text { Humanities? }\end{array}$ & $\begin{array}{l}\text { Natural-Humanities } \\
\text { cards }\end{array}$ & Schoolyard & \multirow[b]{2}{*}{$\begin{array}{l}2 \text { lesson } \\
\text { hours }\end{array}$} \\
\hline & $\begin{array}{l}\text { Activity } 6 \\
\text { Journey to } \\
\text { Nature }\end{array}$ & Transportation & $\begin{array}{l}\text { Kaynaklar } \\
\text { village (land, } \\
\text { scouting and } \\
\text { extreme sports } \\
\text { center) }\end{array}$ & \\
\hline \multirow{3}{*}{$\begin{array}{l}\text { 4.Week } \\
\text { Weather }\end{array}$} & $\begin{array}{l}\text { Activity } 7 \\
\text { How's the } \\
\text { Weather? }\end{array}$ & $\begin{array}{l}\text { Weather Ribbon, work } \\
\text { sheet (How's the } \\
\text { weather?) }\end{array}$ & Schoolyard & $\begin{array}{l}1 \text { lesson } \\
\text { hours }\end{array}$ \\
\hline & $\begin{array}{l}\text { Activity } 8 \\
\text { Weather in } \\
\text { Buca }\end{array}$ & $\begin{array}{l}\text { Working sheet } \\
\text { (weather), thermometer, } \\
\text { weather symbol papers }\end{array}$ & $\begin{array}{l}\text { House } \\
\text { (Balcony, } \\
\text { Front of } \\
\text { window) } \\
\end{array}$ & $\begin{array}{l}\text { Homewor } \\
\mathrm{k}\end{array}$ \\
\hline & $\begin{array}{l}\text { Activity } 9 \\
\text { Travel to } \\
\text { Meteorology }\end{array}$ & Transportation Vehicle & $\begin{array}{l}\text { Meteorology } 2 . \\
\text { Regional } \\
\text { Directorate }\end{array}$ & $\begin{array}{l}3 \text { lesson } \\
\text { hours }\end{array}$ \\
\hline \multirow{3}{*}{$\begin{array}{l}\text { 5.Week } \\
\text { Where I } \\
\text { Live }\end{array}$} & $\begin{array}{l}\text { Activity } 10 \\
\text { We're } \\
\text { Studying The } \\
\text { Map }\end{array}$ & $\begin{array}{l}\text { Maps of the world and } \\
\text { Turkey, color elevation } \\
\text { step }\end{array}$ & Schoolyard & $\begin{array}{l}1 \text { lesson } \\
\text { hours }\end{array}$ \\
\hline & $\begin{array}{l}\text { Activity } 11 \\
\text { I Travel } \\
\text { Around }\end{array}$ & $\begin{array}{l}\text { Means of Transport, } \\
\text { Work sheet (where I } \\
\text { live) }\end{array}$ & $\begin{array}{l}\text { Buca İZBAN } \\
\text { station, Forbes } \\
\text { Street, } \\
\text { Mevlana } \\
\text { statue, Şahin } \\
\text { Hill, Konak, } \\
\text { İnciraltı } \\
\end{array}$ & $\begin{array}{l}3 \text { lesson } \\
\text { hours }\end{array}$ \\
\hline & $\begin{array}{l}\text { Activity } 12 \\
\text { My İzmir }\end{array}$ & Work sheet (My İzmir) & $\begin{array}{l}\text { Places to visit } \\
\text { during the } \\
\text { activities }\end{array}$ & - ? \\
\hline \multirow[t]{2}{*}{$\begin{array}{l}\text { 6.Week } \\
\text { Let's } \\
\text { Prepare For } \\
\text { Natural } \\
\text { Disasters }\end{array}$} & $\begin{array}{l}\text { Activity } 13 \\
\text { We're Going } \\
\text { to AFAD }\end{array}$ & $\begin{array}{l}\text { Transportation vehicle, } \\
\text { water, Styrofoam }\end{array}$ & $\begin{array}{l}\text { Yedigöller } \\
\text { Park, } \\
\text { Provincial } \\
\text { Disaster and } \\
\text { Emergency } \\
\text { Directorate }\end{array}$ & $\begin{array}{l}2 \text { lesson } \\
\text { hours }\end{array}$ \\
\hline & $\begin{array}{l}\text { Activity } 14 \\
\text { We are ready }\end{array}$ & $\begin{array}{l}\text { Turkey Earthquake } \\
\text { Map-earthquake bag }\end{array}$ & Schoolyard & $\begin{array}{l}2 \text { lesson } \\
\text { hours }\end{array}$ \\
\hline
\end{tabular}




\begin{tabular}{lll} 
for & materials & \\
Earthquake! & & Fire and \\
\hline & & Natural \\
Activity 15 & & Disaster \\
Moment of & Transporttaion Vehicle & Training \\
Earthquake & & Center \\
& &
\end{tabular}

The main purpose of the outdoor education practices is to enable the student to take an active role in the learning environment. In order to achieve this, the student must first be aroused by the sense of curiosity and interest. Since the student will only want to take a more active role in the areas he / she is interested in, every subject in the education programs should be planned and put into practice activities that will attract the interest of the student and arouse interest in the student. The most enduring practice in learning is the practice in which students learn by doing, living, observing and experiencing themselves. Therefore, the subjects that the student travels, sees, does, and experiences make it easier to learn than the subjects that the student studies in the classroom by simply reading, writing, and listening. The implementation process and implementation of the activity program (Table 5) prepared in accordance with these principles is explained below.

First week. The course was started by explaining direction, why direction is necessary, how it is found and methods of finding direction. It is found in inferences regarding the location of any place in its vicinity location analysis is performed in terms of proximity to natural and human elements and distance with acquisition and directions. Natural and technological direction finding methods and tools are addressed. Activity 1 and activity 2 were made for the statement.

Activiy 1- My methods of finding directions. The method of finding directions according to the Sun was applied by all students in the school yard. In the morning, students were allowed to stand and open their arms with their right arms facing the direction of the sun rising, and said, in this case, our right arm shows the direction of East and our left arm shows the direction of West. The direction we face is North, and the direction behind us is south explained. Students were asked to look for the Polar Star in the evening as homework by referring to the direction finding method ("when we turn our face to the Polar Star, our front shows the north, our back shows the south, our right shows the east and our left shows the west"). Then we left the school and went to the park closest to the school to show the method of finding direction with the stick and the direction was found by planting the stick in the park. Then the field (pond) was visited and students were asked to find the moss in the trees and stones. It has been reported that "the north-facing side of tree trunks, stones and rocks is often covered with moss", where trees and stones can be used to find directions in a wooded area or open land. After finding the north in this way, students were asked to find mossy sides of trees and stones and to make direction determination. The students were then asked to find an ant nest, and the students were asked to look at the ant nest and find directions ("the ants are piling the soil they have removed from the underground into the mouth of 
their nest, and this soil pile is predominantly North." information has been given. Then we went to a nearby graveyard and looked at the graveyards and found out how to find the direction (head parts of the graveyrd indicate the west, foot parts indicate the East). Stopped in a park on the way back to school and handed out compasses to students, about finding directions by compass and compass ("we can find directions most easily using compass, and when the compass is held horizontally the colored tip Always points north.") information provided. Students were provided to find directions individually by compass. After arriving at the school, information was given about finding directions in the school yard using the clock method and the application of finding directions with the clock was made. Students with non-hours were grouped and all students were allowed to participate in the practice. Then, the GPS device was introduced to the students and the GPS technology, which works on satellites orbiting the earth, provided a navigation demonstration.

Activity 2- I find My Target. In order to reinforce the concept of the place and direction they learned in the previous course, an artificial environment was prepared as a neighborhood model containing the important addresses of the place they lived in the school yard (municipality, pharmacy, transportation station, shopping center...) and then the students were shown about their location (directions are found). Students are then divided into 2 groups and given their goals (goal cards showing their starting and arrival points). Students with Target order 1 were guided to arrive at their destination by voice. Guiding questions by friends as students search for their goals ("which direction is the Refuge according to you?") was asked. Then the students have to say out loud how they have reached their goals (I went 6 steps North, forward from Mall street, etc.) requested. Students who did wrong were guided and guided and provided to achieve the goal. In addition, students who have lost their orientation are given the opportunity to arrive at their destination by looking at the direction arrow found in the corners of the neighborhood models. Students who have made mistakes in this practice have also been mentored.

Second week. Sketch map, bird's eye view, safe spaces and their importance were explained and the lesson was started. He sketches the places he uses in his daily life. Acquisition and shelter, emergency gathering place, emergency exit and other safe areas are shown on the sketch. Activity 3 and Activity 4 were made for the statement.

Activity 3-Sketch Map Drawing. Students were asked to draw a sketch of their neighborhood starting from the starting points indicated by the target cards they used in the previous lesson by dividing them into two groups with the neighborhood model created to represent the place they lived in the previous week. Students who have finished their drawings have been given the opportunity to make criticism by replacing the "I draw a sketch" study sheet with a friend next to them for evaluation. As stated in the acquisition, the areas such as shelter, emergency meeting place, and emergency exit were guided to be shown on the sketch.

Activity 4- I Need to Know the Safe Places. Information has been provided on why the shelter, emergency gathering place, emergency exit and other safe areas are necessary and important. The school and the surrounding area were then identified as 
safe areas. The shelter status within the school was checked and the emergency exits and then the emergency gathering place were identified. Finally, discussion was allowed at the emergency meeting place. As a result of the discussion, acquisition evaluation forms were filled out.

Third week. The course was started by explaining what the natural and human elements are, the elements in the environment and their importance. "Distinguishes natural and human elements in the environment in which he lives." Attainment and students are provided to know their immediate surroundings with all their elements. Activity 5 and Activity 6 were made for the statement.

Activity 5-Natural? Humatities. Natural-human element cards are distributed and students are divided into natural element group and human element group. The first group was asked to show the natural elements formed without touching human hands around them and to bring samples (stone, soil, leaves, tree branches, etc.). The second group was asked to show human elements made by people around them and to bring samples (house, car, bank, pet bottle, waste paper etc.). Students were then given time to find elements in the schoolyard. Students were asked to explain the elements they brought by justifying them according to their groups. Then the groups were changed and given the opportunity to re-gather elements and finally the discussion ("is grass a natural or human element?", "Is the bird's nest natural or human?”...) performed.

Activity 6- Journey to Nature. In order to consolidate the natural and human elements, the resources village was visited. In order to explain the acquisition within the means of transportation to the students in the round trip and return process, all elements of their immediate surroundings (e.g. the knowledge that bridges, roads, human beings, the sky, trees are natural) are mentioned by making explanations. They were given the opportunity to comment and discuss all kinds of distinctions, from trees to lakes, streams to bridges, mountains to power poles and roads. In the open field (land), students are given the opportunity to study the natural and human elements and to explore and find the elements individually. Students are given the opportunity to recognize nature, touch stone, soil and tree, and to recognize elements such as sky, mountains, forests. Finally, students are given the opportunity to study nature (trees, plants, soil, and animals). On the way back, the investigations were divided into groups and discussed, "are natural elements important or human elements? The debate was held.

Forth week. Weather activity, weather and meteorological science were explained and the course was started. Observing the weather events occurring in its vicinity, it transfers its findings to illustrated graphs. The acquisition and duration of the students' observation is determined in such a way as to allow the observation of different weather activities. It also focuses on graph reading and rendering skills when transmitting weather events. Activity 7, 8 and 9 were made for the statement.

Activity 7- How's the Weather. The school yard has a weather strip that includes two weeks of all weather events with different temperature degrees and visuals to a place where all students can see. The students table contains a chart of the weather and weather events, "how about that weather? They were given work sheets and asked to fill 
the work sheets by looking at the weather strip. The students were guided on this subject with an emphasis on graphic reading and creation skills in line with the acquisition description during the creation of the air strip.

Activity 8- Weather in Buca. The students were given a thermometer, weather symbol paper and a work sheet "weather in Buca" containing a weekly weather chart and a chart of weather activities in order to observe the weather activities where they live and transfer their findings to illustrated charts. They were asked to put thermometers on their balconies or in front of their houses' windows and note the daily weather for a week and transfer them to work sheets with illustrated graphics.

Activity 9- Meteorology for Travel. The permits and interviews were completed before the course and the meteorological station was visited. At the meteorological station, information is given through the authorities about how the weather forecast takes place, what are the old and new weather forecasting tools, instant weather monitoring (balloon flying) and monitoring, tasks of the institution, meteorological instruments and concepts.

Fifth week. Maps, the importance and types of maps, the population and geographical features of the place where we live were explained and the lesson was started. "It makes inferences about the landforms and population characteristics of the place where it lives and its surroundings. Acquisition and the political and Physical Map of Turkey are examined together with the students. While this acquisition is being processed, literary products such as poetry, story, saga are utilized. Activity 10.11 and 12 were made for the announcement.

Activity 10-We're Studying the Map. In the schoolyard, political maps (world, Turkey, Aegean region, İzmir, Buca) and physical maps (world, Turkey, Aegean region, İzmir, Buca) are placed in strips in two different places, close away (from Buca to Earth). Students were divided into two groups, the first group was asked to find political maps and the second group was asked to find their neighborhoods, districts, cities and countries. The groups were then given the opportunity to examine each map, while the teacher asked the students specific questions (physical characteristics, neighbors, direction and location, etc.) directed. Individual guidance was given to students who were unable to find positions or were forced out.

Activity 11- I Travel Around. "Where I live" study sheet has been given in a format that has been reduced to their level (so that they can understand) in order for the students to code the places they visit and see. Starting from their own schools, IZBAN station, Forbes Street, Mevlana statue, Şahin Hill, Konak, İnciraltı were provided to see and observe different places in terms of height and population. During this tripobservations, students were asked to describe the places they traveled and the places they traveled to the study sheets were low, flat, high and sparsely populated, crowded, etc. their coding has been guided by their statements.

Activity 12- My İzmir. Reading poems and stories about İzmir and determining geographical and population characteristics of the students were played. After the end of all activities, they were asked to write poems, epics, stories on the "My İzmir" study 
sheet about their experiences on the way back, and they were allowed to share the texts they wrote with their friends. Each shared text has been discussed in scientific and ethical terms.

Sixth week. Natural activities, natural disasters and their types, the importance for our country has been explained and the lesson has been started. Makes the necessary preparations for natural disasters acquisition and priority is given to natural disasters that are likely to encounter in the environment in which the student lives. Earthquake bag preparation topic is addressed the activity for the description 13.14 and 15 were made.

Activity 13- We're Going to AFAD. After leaving school, a park or open area on the way to the students are less likely to see disasters (floods, landslides, and avalanches) were stopped in order to introduce. Flood with enough water (a waterway was opened on the sloping slope, with pet bottle waters, too much water was poured suddenly with the students. Thus, the waterway was unable to carry the spilled water and the flood image was revealed) and landslide-landslide (the sloping slope used for flood demonstration ensured that the soil was softened on the ground and by intervention the soil was shifted due to the weight of the water) were shown. Then Styrofoam and avalanches (Styrofoam were left with students from the sloping slope, the accumulated on top of each other could not carry more load and moved downwards.) representation, are reviewed. Then, the permits and negotiations were completed before the course and Disaster and Emergency Management Presidency went to the İzmir Provincial Directorate of disaster and Emergency Management. After "basic disaster awareness training" was given by the authorities at AFAD, information about preventing and preventing disasters, especially earthquakes, was given at the training site of the institution. Finally, disaster response equipment was introduced.

Activity 14- We're Ready for an Earthquake. Turkey Earthquake Map was examined in the school yard and the importance of the earthquake was noted for our country. Then, the students were guided to prepare an earthquake bag first individually and then as a group with the materials they brought from their homes. Earthquake bags were then prepared by changing the materials of groups and individuals. In addition, individual Earthquake Information Card preparation has been guided. After that, many different materials were placed on the ground in the school yard, and the students chose from these materials in groups for the earthquake bag and prepared their own earthquake bags. Questions were asked about why they chose or did not choose the materials they chose and students were allowed to discuss them. (Why did you put the hammer in the earthquake bag? Why is it necessary?) Then an earthquake drill was carried out.

Activity 15- Moment of Earthquake. The permits and interviews were completed before the course and the fire and Natural Disaster Training Center was visited. First, a fire search and rescue operation was monitored at the training site by the authorities, then information was given by the authorities about the fire, search and rescue in the wrecks, chemicals and emergency situations. In addition, practical training field trip, the introduction of disasters and basic disaster awareness training after, 
before, during, and after the earthquake information is given. The students were then divided into groups and entered the earthquake house simulator in order to feel the moment of the earthquake. Thus, the students experienced the earthquake moment in practice and the authorities intervened on what needs to be done. Upon return, students are given a "family earthquake plan" form to be filled out with their families as homework.

\section{Data Analysis}

The AAT data applied as pre-test, post-test and persistence tests were analyzed using the SPSS 23 package program. Frequency and percentage analyses were used to describe the personal information of the students in the study group. An independent sample t-test was applied to determine whether the test and control group pre-test score averages differed from each other.

The "Academic Achievement Test" was applied to the experiment and control groups as a pre-test, post-test and persistence test in terms of data creation of the study. In this respect, the analysis of the data was decided to be done with "two-way ANOVA for Mixed Measures", a variance analysis for "comparison of average scores in mixed measurements" in mixed designs adopted in most experimental studies in educational sciences (Büyüköztürk, 2017).

In this study, it was decided to use two-factor ANOVA for mixed measurements to investigate the effect of outdoor educational activities and outdoor teaching method (independent variable) on students ' academic achievement and level of remembrance (dependent variables). But before that, this model, also called "Two-Factor Anova for repeated measurements", needs to meet some assumptions in order to be implemented (Büyüköztürk, 2017). First, the satisfaction states of these assumptions were tested. After evaluating all controls based on the results of the test of assumptions, it was concluded that the necessary assumptions were met and that the applicability of the test was appropriate in order to perform a two-way variance analysis test for mixed measurements.

\section{Findings}

"Does outdoor education have an impact on students' academic achievement and their level of remembering knowledge in the fourth grade social studies course?" the analysis of the data obtained on the solution of the basic problem sentence, the findings and interpretations of the findings as a result of the analyses were given. These data are presented in tables in accordance with the sub-problems involved in the purpose of the research. Parametric tests were performed due to the sufficient number of data, the normal distribution of the shapiro-wilks test result, the equality of covariance matrices (Box's M) and the homogeneity of the variances (Levene F) in the analysis of the data obtained from the research. Descriptive statistics for the quantitative findings obtained from the analysis of the data are given in Table 6. 
Table 6

Descriptive statistics from social sciencees course academic achievement test

\begin{tabular}{lccccccc}
\hline \multirow{2}{*}{ Group } & \multicolumn{3}{c}{$\begin{array}{c}\text { Achievement } \\
\text { Pre-test }\end{array}$} & $\begin{array}{c}\text { Achievement } \\
\text { Post-test }\end{array}$ & \multicolumn{2}{c}{ Recall } \\
\cline { 2 - 8 } & $\mathrm{N}$ & $\overline{\mathrm{x}}$ & $\mathrm{S}$ & $\overline{\mathrm{x}}$ & $\mathrm{S}$ & $\overline{\mathrm{x}}$ & $\mathrm{S}$ \\
\hline Experiment & 33 & 11.48 & 2.94 & 18.21 & 1.79 & 18.18 & 1.62 \\
\hline Control & 31 & 11.41 & 2.56 & 16.12 & 2.34 & 13.68 & 2.21 \\
\hline
\end{tabular}

As can be seen in Table 6, changes in success and persistence levels in experiment and control groups were examined in detail under findings and comments on the first and second sub-problem.

\section{Findings on the First Sub-Problem}

"Is there a significant difference between pre-test and sontest scores in the test and control group Academic Achievement Test?" in order to solve the sub-problem, the data obtained from the participants were analyzed using two-way variance analysis.

The arithmetic mean and standard deviation scores obtained by the groups as a result of the pre-and sontest application of the academic achievement test prior to Anova are given in Table 7.

Table 7

Pre-test and post-test average score and standard deviation values of the groups from the academic achievement test

\begin{tabular}{lccccc}
\hline \multirow{2}{*}{ Group } & \multicolumn{3}{c}{ Pre-test } & \multicolumn{2}{c}{ Post-test } \\
\cline { 2 - 6 } & $\mathbf{N}$ & $\overline{\mathbf{x}}$ & $\mathbf{S}$ & $\overline{\mathbf{x}}$ & $\mathbf{S}$ \\
\hline Experiment & 33 & 11.48 & 2.94 & 18.21 & 1.79 \\
\hline Control & 31 & 11.41 & 2.56 & 16.12 & 2.34 \\
\hline
\end{tabular}

When Table 7 is examined, the arithmetic averages of the success test scores of the groups are seen as prestest $(\overline{\mathrm{X}} \mathrm{DG}=11.48$ and $\overline{\mathrm{X}} \mathrm{KG}=11.41)$ and sontest $(\overline{\mathrm{X}} \mathrm{DG}=18.21$ and $\overline{\mathrm{X}} \mathrm{KG}=16.12$ ).

A two-way variance analysis of the differences between pre-and sontest in the academic achievement scores of the experiment and control group Students showed a significant difference and the results are given in Table 8.

Table 8

Anova results of the pre-and post-test academic achievement test scores of the groups

\begin{tabular}{|c|c|c|c|c|c|c|}
\hline Source of Variance & KT & sd & KO & $\mathbf{F}$ & $\mathbf{p}$ & $\eta 2$ \\
\hline \multicolumn{7}{|l|}{ Between of Groups } \\
\hline In Group (Experiment/Kontrol) & 36.895 & 1 & 36.895 & 4.96 & .029 & .074 \\
\hline Mistake & 460.324 & 62 & 7.425 & & & \\
\hline \multicolumn{7}{|l|}{ Groups } \\
\hline Achievement (Pre-test-Post-test) & 1045.409 & 1 & 1045.409 & 227.849 & .000 & .786 \\
\hline Achievement*Group & 32.534 & 1 & 32.534 & 7.09 & .010 & .103 \\
\hline Mistake & 284.466 & 62 & 4.588 & & & \\
\hline
\end{tabular}


1. There is a significant difference between the pre-test and post-test achievement total achievement scores of the test and control group $[\mathrm{F}(1 ; 62)=4.96, \mathrm{p}<.05]$. This finding shows that the academic achievement scores of the students in the experiment group and control group differed without distinction of measurement (before and after the experiment).

2. There is a significant difference between the pre-and post-test average academic achievement scores in relation to the academic achievements of the social studies course of the experiment and control group students $[\mathrm{F}(1 ; 62)=227.849, \mathrm{p}<.05]$. This finding can be interpreted as that the academic achievement of the students ' social studies course, regardless of group, varies depending on the teaching method applied.

3. Two different teaching methods applied to the experiment group and the control group in academic achievement test scores of students before and after the experiment, showed significant differences in different groups at different times with being in process measurements on the levels of the factors, indicating the joint effects of academic achievement was found to be significant $[\mathrm{F}(1 ; 18)=7.09, \mathrm{p}<.05]$. This finding shows that the methods applied in increasing the scores of the class students (experiment group) where the outdoor teaching method is applied and the class students (control group) where the outdoor teaching method is not applied have different effects. It can be said that these differences observed in the academic achievements of the experimental and control group Students are due to the outdoor teaching method. In this case, it is understood that the outdoor teaching method is an important factor in increasing the success levels of the students compared to in-class teaching.

According to the effect size (Büyüköztürk, 2017) statistic showing how effective the independent variable is on the dependent variable and intended to increase the intelligibility of the results, the group (experiment-control) is at a moderate level $(\eta 2=.074)$, measuring (pre-test,post-test) on the broad level $(\eta 2=.786)$ and moderate effect magnitude on group-measurement(experiment/control-preest/sontest) $(\eta 2=.103)$ appears to have. 


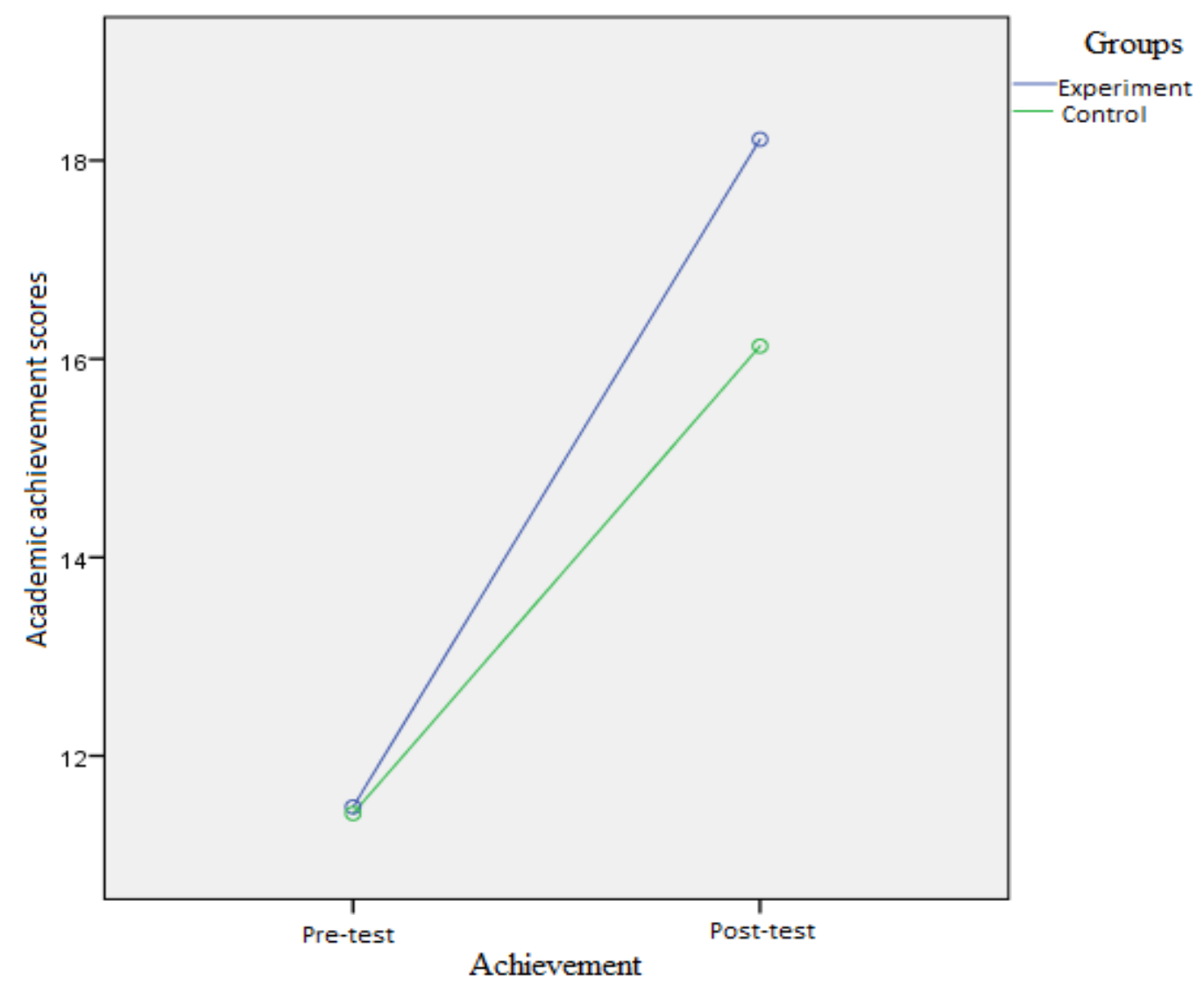

Figure 2. The Diagram showing the preliminary-final success scores of the experiment and control group Students for the social studies course

When figure 2 is examined, it is observed that the academic achievement scores of the experiment and control group students increase according to the pre-test measurement of post-test. The results of the analysis of the data showed that activities based on the outdoor teaching method applied in social studies course had a positive effect on the success levels of the students.

\section{Findings on the Second Sub-Problem}

"Is there a significant difference between test and control group Academic Achievement Test, post-test and recall test scores?" in order to solve the sub-problem, the data obtained from the participants were analyzed using two-way variance analysis.

The arithmetic mean and standard deviation scores obtained by the groups as a result of the application of the Academic Achievement Test as post-test and recall test prior to Anova are given in Table 9. 
Table 9

Post-Test And Recall Mean Scores and Standard Deviation Values of the Groups from the Academic Achievement Test

\begin{tabular}{lccccc}
\hline \multirow{2}{*}{ Group } & \multicolumn{3}{c}{ Post-test } & \multicolumn{2}{c}{ Recall } \\
\cline { 2 - 6 } & $\mathrm{N}$ & $\overline{\mathrm{x}}$ & $\mathrm{S}$ & $\overline{\mathrm{x}}$ & $\mathrm{S}$ \\
\hline Experiment & 33 & 18.21 & 1.79 & 18.18 & 1.62 \\
\hline Control & 31 & 16.12 & 2.34 & 13.68 & 2.21 \\
\hline
\end{tabular}

In table 9, the arithmetic averages of the achievement test scores of the groups are given as post-test $(\overline{\mathrm{X}} \mathrm{DG}=18.21$ and $\overline{\mathrm{X}} K G=16.12)$ and persistence test $(\overline{\mathrm{X}} \mathrm{DG}=18.18$ and $\overline{\mathrm{X}} \mathrm{KG}=13.63$ ).

The two-way variance analysis of the social studies students ' academic achievement scores after the application and 4 weeks after the application showed a significant difference and the results are given in Table 10.

Table 10

Anova Results of the Post-Test and Recall Academic Achievement Test Scores of the Groups

\begin{tabular}{lllllll}
\hline \multicolumn{1}{c}{ Source of Variance } & KT & sd & KO & F & p & $\boldsymbol{\eta 2}$ \\
\hline Between of Groups & & & & & & \\
\hline Group (Experiment/Control) & 346.821 & 1 & 346.821 & 63.73 & .000 & .507 \\
\hline Mistake & 337.359 & 62 & 5.441 & & & \\
\hline In Group & & & & & & \\
\hline Achievement(Post-test-Recall) & 49.231 & 1 & 49.231 & 18.68 & .000 & .232 \\
\hline Achievement*Group & 46.856 & 1 & 46.856 & 17.78 & .000 & .223 \\
\hline Mistake & 163.324 & 62 & 2.634 & & & \\
\hline
\end{tabular}

1. There is a significant difference between the total achievement scores of academic achievement sontest and recall of the social studies course after the experiment and the control group $[\mathrm{F}(1 ; 62)=63.73, \mathrm{p}<.05]$. This finding shows that the academic achievement scores of the students in the experiment group and control group differed without distinction of measurement (after the experiment and 4 weeks after the experiment).

2. There is a significant difference between post-test and persistence average achievement scores in relation to social studies course achievements of experiment and control group students $[\mathrm{F}(1 ; 62)=18.68, \mathrm{p}<.05]$. This finding can be interpreted as that the success of the students ' social studies course without group discrimination varies depending on the teaching method applied.

3. Two different teaching methods applied to experiment and control group students after the experiment differs greatly from the recall of the academic achievement test points, since the measurements at different times, indicating different process of remembering the information being in groups the joint effects on the levels of the factors was found to be significant $[\mathrm{F}(1 ; 18)=17.78, \mathrm{p}<.05]$. This finding shows that the scores of the class students applied to the outdoor teaching method and the approaches 
applied to increase the recall scores of the class students not applied to the outdoor teaching method have different effects. It can be said that these differences in the level of remembering students ' knowledge are due to the outdoor teaching method. In this case, it is understood that the outdoor teaching method is an important factor in improving the students ' level of remembering their knowledge according to in-class teaching.

When the effect magnitudes are evaluated, the group (experiment-control) over $(\eta 2=.507)$, on the measurement (pre-test-post-test) $(\eta 2=.232)$ and large levels of influence magnitude on group-measurement (experiment/control-pre-test/post-test) $(\eta 2=.223)$ was found to have.

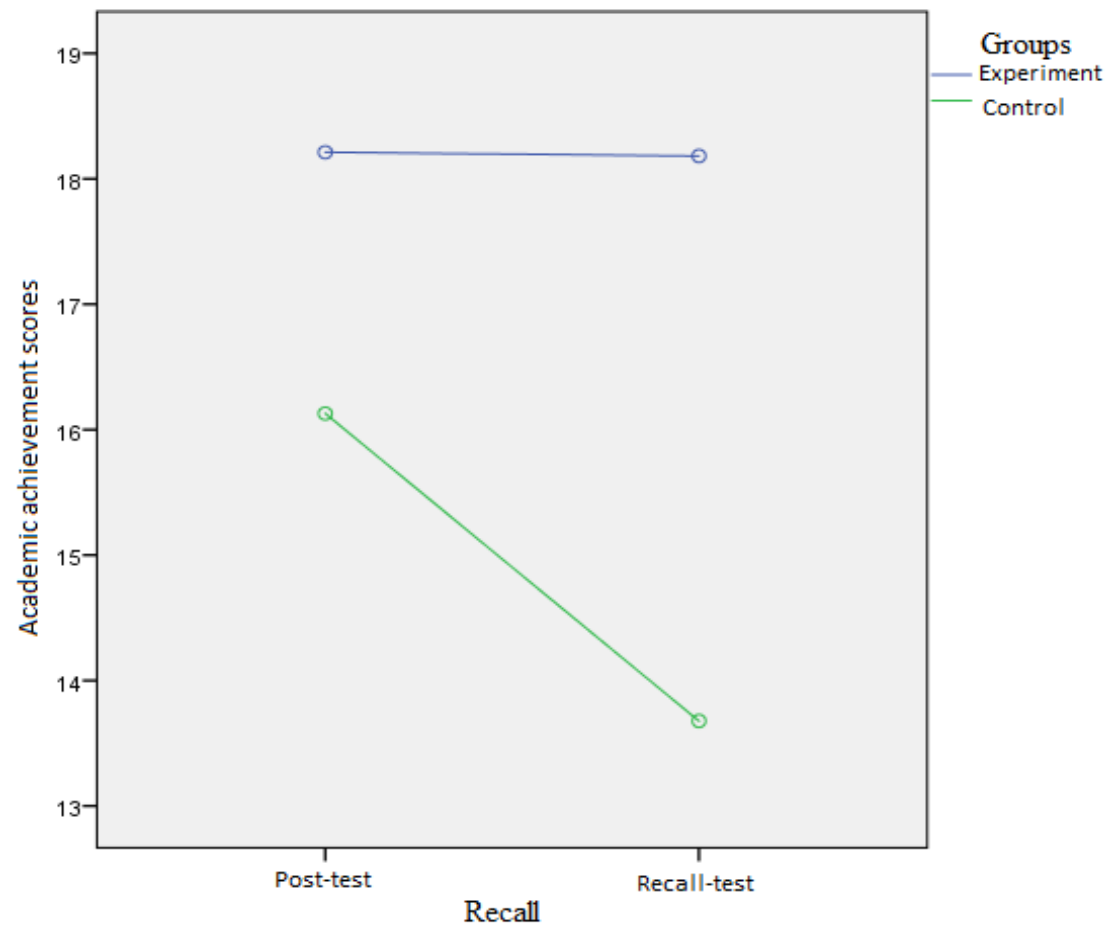

Figure 3. The diagram showing post-test and recall test achievements scores for the social studies lesson of the experiment group and control group students

When figure 3 is examined, it is observed that the academic achievement scores of the students in the experiment group remained the same (with a decrease of 0.3) compared to the post-test measurement of the recall test and that the control groups showed a decrease. The results of the analysis of the data showed that activities based on the outdoor teaching method applied in the social studies course had a positive effect on the students' level of remembering their knowledge.

\section{Discussion}

\section{Discussion on the First Sub-Problem}

The first sub-problem of the study was "Is there a significant difference between the pre-test and post-test scores in the experiment and control group academic achievement 
test? It is stated as". In order to examine the effects of the teaching method on academic success in the teaching of "people, places and environments" learning area subjects within the scope of Social Studies Courses, The Academic Achievement Test was applied as preest and sontest to the experiment and control group. In line with the findings, the following results were discussed.

The results of the analysis of the pre-test and post-test data on the academic achievement test applied to the experiment and control group students showed a significant difference. The achievement levels of the experiment group students in the "people, places and environments" learning area were higher than the achievement levels of the control group students. Pre-test and abt the contest results implemented as applications (outdoor teaching methods and activities-social studies curriculum content and activities) bring about an increase in the success of the experiment group and the control group did also, but this increase has shown that students in the experiment group more than control group students occur. This has shown that social studies courses in the experiment group have a stronger impact on students' academic achievement by using outdoor educational activities and teaching methods. In the literature studies showing that outdoor education increases the academic achievement levels of the students are found (Ahmad, 2014; Ay, 2015; Bakioğlu, 2017; Borsos, Borić and Patocskai, 2018; Çetin and Metin, 2013; Kaleli, 2018; Karakaş, Özür and Şahin, 2017; Özkan, 2009; Taşoğlu, 2010). In this study, it can be said that outdoor education has a positive effect on students' achievement levels and this result parallels the results from similar studies.

Outdoor education contributes to students ' academic achievement by providing an interdisciplinary active learning environment on specific topics and content in many courses (Stoecklin, 2009). In the outdoor education process, students explore using their senses while learning actively throughout their education activities (Fägerstam, 2013) and thus become involved in the learning process by living by doing (Dillon, 2012). To be seen as an excellent opportunity to promote meaningful learning outside the classroom educational practices (Berman, Jones and Kaplan, 2008), is attractive to students because it is different from the applications in the classroom (Saraç and Çiçek, 2017), and in this way offers a more comfortable learning experience for students and increases class participation (Alba, 2011). In addition, outdoor education allows students to see and embody subjects (Çepni and Aydın, 2015) and make connections to the real world outside the classroom, thus contributing to meaningful learning (Alba, 2011) and increasing academic achievement (Looney, 2015). In this respect, it can be said that the practice of outdoor educational activities and teaching methods have a positive effect on the students' attainment of meaningful and lasting information and their attainment levels.

\section{Discussion on the Second Sub-Problem}

The second sub-problem of the study was "Is there a significant difference between the test and control group academic achievement test post-test and recall test scores? it is stated as". In order to examine the impact of outdoor educational activities and teaching method on information recall level in the teaching of "people, places and 
environments" learning area subjects within the scope of social studies course, the academic achievement test was applied to the experiment and control group as the posttest and recall test. In line with the results obtained, the following results were discussed. The results of the analysis of the academic achievement test post-test and recall test data applied to the experiment and control group students showed a significant difference. The experiment group students had higher levels of remembering students 'knowledge of" people, places and environments" learning area subjects than the control group students had higher levels of remembering their knowledge. The AAT results applied as the sontest and recall test showed that the students' memory of information continued at the same level in the experiment group (outdoor teaching method and activities-social studies curriculum content and activities), while in the control group there was a decrease in the memory level of information. This has shown that the processing of social studies lessons in the experiment group by outdoor educational activities and teaching method has a stronger effect on the recall of students' knowledge.

In the field of literature, studies have shown that outdoor education positively affects students' ability to remember their knowledge (Achor, Ogbeba and Samuel, 2014; Ahmad, 2014; Falk and Dierking, 1997; Harris and Bilton, 2019). In this study, it can be said that outdoor education has a positive effect on the students ' level of remembering their knowledge and this result parallels the results from similar studies in the literature. One goal of education (MoNE, 2017), which aims to provide students with the knowledge, skills, attitudes, behaviors and habits necessary to become a good citizen or even a good person, is that these attainments are permanent in the long term. In the knowledge dimension, the student can attainment permanence when he / she learns by living by doing a knowledge (Büyükkaragöz and Çivi, 1999). The outdoor education to make the students active throughout the process (James and Williams, 2017), an event, a situation, and to recognize the opportunity for observation and study of objects in place (Johnson according to from from Hodge, 2004) concrete learning help you to attainment meaningful observing (Balkan Kıyıcı and Atabek Yiğit, 2010) and the training experiences that occurred in the environments many students they can use their senses to enable them to live effectively for reasons such as the persistence of information allows you to increase the levels of (Alba, 2011). In this way, it can be said that it is easier for students to remember the information they have acquired through the application of outdoor educational activities and teaching method in teaching social studies course, and that it has a positive effect on the attainment of permanent learning and increasing the level of remembering information.

\section{Result}

It can be said that the fourth grade social sciences course "People, Places and Environments" learning area subjects are seen and embodied by the students, that the students learn by doing-living, that they use their many senses by actively participating in the learning process, that they learn on the spot through firsthand observations and investigations, that the learning takes place in an effective and meaningful way and that Based on these reasons, the results of this study showed that the students in the experiment group had an increase in the level of remembering their knowledge after the 
learning process. Based on the relevant literature and research findings, it can be said that activities based on the outdoor teaching method positively affect the level of recall of information. One of the aims of education is, without doubt, that the knowledge gained is permanent. It is known that many teaching methods and techniques are still being used in education in order to provide students with permanent knowledge, and new pursuits are continuing. In this respect, it is important to determine the results of a teaching method that can be used for students to acquire and learn permanent knowledge through experimental practice. One of the most important results of this study is that the level of remembering the knowledge of the experimental group students for the application of the outdoor education which has many benefits in different ways in the teaching process increased according to the control group. The study concluded that outdoor education had a positive effect on the students ' level of remembering their knowledge and that recall learning took place.

It can be said that the fourth grade social studies lesson "People, Places and Environments" learning area subjects are seen and embodied by the students, that the students learning by doing, that they use their many senses by actively participating in the learning process, that they learn on the spot through firsthand observations and investigations, that the learning takes place in an effective and meaningful way and that. Based on these reasons, the results of this study showed that the students in the experimental group had an increase in the level of remembering their knowledge after the learning process. Based on the relevant literature and research findings, it can be said that activities based on the outdoor teaching method positively affect the level of recall of information. One of the aims of education is, without doubt, that the knowledge gained is permanent. It is known that many teaching methods and techniques are still being used in education in order to provide students with permanent knowledge, and new pursuits are continuing. In this respect, it is important to determine the results of a teaching method that can be used for students to acquire and learn permanent knowledge through experimental practice. One of the most important results of this study is that the level of remembering the knowledge of the experimental group students for the application of the outdoor education which has many benefits in different ways in the teaching process increased according to the control group. The study concluded that outdoor education had a positive effect on the students ' level of remembering their knowledge and that permanent learning took place.

\section{Recommendations}

The schoolyard should be organized like a learning environment and made functional so that all kinds of activities can take place.

Instead of using the schoolyard only for recess and for the processing of certain courses, it should be ensured that the subject and content of almost every course are actively utilized in teaching. Allowances should be allocated to schools for activities outdoor the school, including field studies, research-study trips, observations, museum visits, institution visits, etc. use in events should be encouraged.Students, parents, teachers and administration should meet in a common denominator, especially for activities to be organized in outdoor learning environments. A certain system should be 
established in order to carry out the procedures with the institution, organization, enterprise to be granted permission and to give quick results in the permit process. Classroom and outdoor learning environments should be determined in local context, formal education and training activities should be carried out in these environments. Trips to outdoor learning environments should be planned in such a way as to allow students to study and observe and learn firsthand.

\section{References}

Achor, E., E., Ogbeba, J., Samuel, A., O. (2014). Effects of school outdoor activities on senior secondary two (ss ii) students' retention in ecology in jalıngo metropolıs, Taraba, Nigeria, Nigeria Educational Forum, 22 (2), 83-95.

Ahmad, Y. (2014). Effects of field-trip on retention and academic achievement in ecology among secondary school students in zaria, Nigeria (Unpublished master's thesis) Ahmadu Bello Unıversity/Faculty of Education, Nigeria.

Alba, F. (2011) Outdoor learning: Practical guidance, ideas and support for teachers and practitioners in Scotland, (corp creator). Retrieved from https://education.gov.scot/ improvement/documents/hwb24-ol-support.pdf.

Aslan, A., Demircioğlu, G. (2018). A review on Turkish graduate studies performed on out-ofschool learning environments. Karadeniz Teknik Üniversitesi Sosyal Bilimler Enstitüsü Sosyal Bilimler Dergisi, 8 (16), 379-402.

Ay, M. (2018). An investigation of preschool teachers' views and practices on outdoor science and mathematics activities (Unpublished master's thesis). Dokuz Eylül Üniversitesi/Eğitim Bilimleri Enstitüsü, İzmir.

Bakioğlu, B. (2017). Effectiveness of out-of-school learning setting aided teaching of the 5th grade let's solve the riddle of our body chapter (Unpublished doctoral thesis). AmasyaÜniversitesi/Fen Bilimleri Enstitüsü, Amasya.

Balkan Kiyıc1, F., Atabek-Yiğit, E,. (2010). Science education beyond the classroom: A field trip to wind power plant. International Online Journal of Educational Sciences, 2 (1), 225-243.

Beard, C., Wilson, J. P. (2006). Experiential learning: A best practice handbook for educators and trainers. Philadelphia, PA: Kogan Page, Limited.

Berman, M. G., Jonides, J., \& Kaplan, S. (2008). The Cognitive Benefits of İnteracting With Nature. Psychological Science, 19 (12), 1207-1212.

Borsos, E., Borić, E., Patocskai, M. (2018). Be in: Teach Outdoors!. Croatian Journal of Education, 20 (3), 843-866. doi: 10.15516/cje.v20i3.2978

Büyükkaragöz, S. ve Çivi, C. (1999). Genel öğretim metotları. İstanbul: Beta Yayınları.

Büyüköztürk Ş. (2017). Sosyal bilimler için veri analizi el kitabı, araştırma deseni SPSS uygulamalart ve yorum. Ankara: Pegem Akademi.

Büyüköztürk, Ş., Çakmak-Kılıç, E., Akgün, E., Ö., Karadeniz, Ş., Demirel, F. (2018). Bilimsel araştırma yöntemleri. Ankara: Pegem Akademi.

Caner, C. (2009). A review of outdoor learning in british columbia's public schools (Unpublished master's thesis). Royal Roads Unıversity, British Columbia.

Çepni, O., Aydın, F. (2015). Social sciences teachers' views on out-of-classroom environments. The Journal of Academic Social Science Studies, 39, 317-335. 
Çepni, S. (2014). Araştırma ve proje çalışmalarına giriş. Trabzon: Celepler Matbaacılık.

Çerkez, S. (2011). Museum education-based teaching social studies course applications on student's academic effects of success and attitudes (Unpublished master's thesis). Kastamonu Üniversitesi/Sosyal Bilimler Enstitüsü, Kastamonu.

Çetin, M., A., Metin, C. (2013). The effects of visiting cemetery and martyrdom to the academic success of students in formation of historical knowledge and consciousnes. Anadolu Ĕ̈itim Liderliği ve Öğretim Dergisi 1 (1), 44-66.

Çiçek, Ö., Saraç, E. (2017). Science teachers' opinions about experience in out of school learning environments. Ahi Evran Üniversitesi Kırşehir Eğitim Fakültesi Dergisi (KEFAD), 18 (3), 504-522.

Cirit Gül, A., Tağrikulu, P., Çobanoğlu, E.,O. (2018). Türkiye'de sınıf dışı eğitim ile ilgili yapılan lisansüstü tezlerin incelenmesi. Sinıf Dışı Öğrenme Sempozyumu Ö̈zetler ve Tam Metinler Kitabl, (s.92-101). Ege Üniversitesi, İzmir.

Dillon, J. (2012). Science, the environment and education beyond the classroom. In B. Fraser, K. Tobin, \& C. J. McRobbie (Eds.), Second International Handbook of Science Education (pp. 1081-1096). London: Springer.

Dirt is good: The Campaign for the Play (2016). Richerd Edelman (President). Retrieved from https://www.edelman.co.uk/insights/dirt-good-campaign-play.

Donaldson, G. E., Donaldson, L. E. (1958). Outdoor education: A definition. Journal of Health. Physical Education and Recreation, 29 (17), 63.

Eaton, D. (1998). Cognitive and Affective Learning in Outdoor Education (Unpublished doctoral thesis). University of Toronto, Canada.

Echazarra, A. (2018), "How has Internet use changed between 2012 and 2015?", PISA in Focus, No. 83, OECD Publishing, Paris, doi: 10.1787/1e912a10-en.

Edlund, C. (2001). Student perceptions of outdoor educational experiences (Unpublished doctoral thesis). Walden University, Minnesota.

Edwards, R. A. (2019. 10. 4). Why 30 minutes of nature a day is so good for your health. Retrieved from https://www.yesmagazine.org/happiness/health-nature-science-outside20190410

English Outdoor Council. (2005). High quality outdoor education. A guide to recognizing and achieving high quality outdoor education in schools, youth services, clubs and centres. London: OEC.

English Outdoor Council. (2015). High quality outdoor learning. London: OEC.

Fägerstam, E. (2013). High school teachers' experience of the educational potential of outdoor teaching and learning, Journal of Adventure Education \& Outdoor Learning, 14 (1), 5681. doi: 10.1080/14729679.2013.769887.

Falk, J., H., Dierking, L. D. (1997). School field trips: Assessing Their long-term impact, Curotor The Museum Journal, 40 (3), 211-218.

Foran, A. (2008). An Outside Place for Social sciences. Canadian Social sciences, 41(1), 1-9.

Ford, P. (1986). Outdoor education: Definition and philosophy. N. Mexico: ERİC Clearinghouse on Rural Education and Small Schools.

Gilbertson, K., Bates, T., Ewert, A., McLaughlin, T. (2006). Outdoor education: Methods and strategies. (Reader version). Retrieved from https://books.google.com.ph/books?id= 
$\mathrm{k} 82 \mathrm{M} 2 \mathrm{yBH} 704 \mathrm{C} \&$ printsec $=$ frontcover\&redir_esc $=\mathrm{y} \# \mathrm{v}=$ onepage $\& \mathrm{q} \& \mathrm{f}=$ false

Ginny, Mother of 5. (2019). Children Should Be Outside for 4-6 Hours Every Day. Retrieved from https://1000hoursoutside.com/1/post/2019/01/children-should-be-outside-for-4-6hours-everyday.html?fbclid=IwAR2QXIqhU2VEfvRSvknq41-

FpMWXi8HGnSwumnTAIgSsGtObgh_MF06ZdcE

Harris, R., Bilton, H. (2019). Learning about the past: Exploring the opportunities and challenges of using an outdoor learning approach, Cambridge Journal of Education, 49 (1), 69-91, doi: 10.1080/0305764X.2018.1442416.

Harveston, K. (2019. 1. 4). Study: Kids Who Spend Time in Nature Become Happier Adults. Retrieved from https://livelovefruit.com/kids-who-spend-time-in-nature-become-happieradults/

Heppner, P. P., Kivlighan, D. M. ve Wampold, B. E. (1999). Research design in counseling. Belmont: Wadsworth Publishing Company.

Hodge, S., L. (2004) Outdoor learning environments: evaluating need, success and sustainability (Unpuplished master's thesis). The University of Texas at Arlington/ Faculty of the Graduate School, USA.

Holland, G., Tiggemann, M. (2016). A systematic review of the impact of the use of social networking sites on body image and disordered eating outcomes, Journal of Elsevier, 17, 100-110. doi: org/10.1016/j.bodyim.2016.02.008.

James, J., K., Williams, T. (2017). School-based experiential outdoor education: A neglected necessity, Journal of Experiential Education, 40 (1), 58-71.

Jirásek, I., Plevová, I., Jirásková, M., Dvořáčková, A. (2016). Experiential and outdoor education: the participant experience shared through mind maps, Studies in Continuing Education, 38 (3), 334-354. doi: 10.1080/0158037X.2016.1141762

Kaleli, C. (2018). The effects of field works on the academic achievement of students in the teaching of the tenth class (Unpublished master's thesis). Ondokuz Mayis Üniversitesi/Eğitim Bilimleri Enstitüsü, Samsun.

Kan, A., Ü. (2018). Eğitime İlişkin Temel Kavramlar. Gömleksiz, M,. N. (Ed.). In Öğretim İlke ve Yöntemleri (s. 19-43). Ankara: Asos Yayıncılık.

Karakaş Özür, N., Şahin, S. (2017). The effect of out of classroom activities on student success in the social studies course. Ahi Evran Universitesi Kırşehir Eğitim Fakültesi Dergisi (KEFAD), 18 (3), 324-347.

Karakuş, U. (2006). The effect of experimental method at students success level while teaching climate subject in geography (Unpublished doctoral thesis). Gazi Üniversitesi/Eğitim Bilimleri Enstitüsü, Ankara.

Kirkpatrick, N. (2019). If you want to feel happier, just spend 20 minutes in nature. Retrieved from https://www.mnn.com/health/fitness-well-being/blogs/urban-park-20-minutes-feelbetter-study?fbclid=IwAR2Snpwoj_Z5EpB--YRHRz2GA0YDDmS92EK0JZiVQ8 ymg6kDzyXO4dLwn8

Looney, C., T. (2015). Teachers experiences with outdoor education (Unpublished doctoral thesis), Northcentral University/Graduate Faculty of the School of Education, Arizona. (3732057)

Loria, K. (2018). Being outside can improve memory, fight depression, and lower blood pressure- here are 12 science-backed reasons to spend more time outdoors. Retrieved 
from https://www.businessinsider.com/why-spending-more-time-outside-is-healthy-20177

Louv, R. (2018). Doğadaki son çocuk, (Temürcü, C, Çeviri Ed.). Ankara: Salmat Basım Yayınc1lk.

Maller, C. J. (2009). Promoting children's mental, emotional and social health through contact with nature: A model. Health Education Journal, 109 (6), 522-542. doi: $10.1108 ? 09654280911001185$.

McGowan, A., L. (2015). Outdoor education integrated curriculum program impact on adolescent self-authorship (Unpublished master's thesis). Minnesota State University, Mankato.

Mcmillan, J. H., Schumacher, S., (2006). Research in education: Evidence Based inquiry. Sixth Edition. Boston, MA: Allyn and Bacon.

Meydan, A. (2015). Okul Dişı Sosyal Bilgiler Öğretiminde Doğa Eğitimi. Şimşek, A ve Kaymakçı, S. (Ed.). In Okul Dışı Sosyal Bilgiler Öğretimi, (s. 259-282). Ankara: Pegem Akademi.

Milli Eğitim Bakanlığı (MEB) (2017). Şehrimiz Dersi (Ortaokul 5, 6, 7 ve 8. Sınıflar) Öğretim Programı. Ankara: T.C Milli Eğitim Bakanlığı Talim ve Terbiye Kurulu Başkanlığı.

Milli Eğitim Bakanlığı (MEB) (2018). İlkokul ve Ortaokul Sosyal Bilgiler Dersi (4, 5, 6, 7.sınıflar) Öğretim Programı. Ankara: T.C Milli Eğitim Bakanlığı Talim ve Terbiye Kurulu Başkanlığı.

Milli Eğitim Bakanlığı (MEB) (2019). Millî Eğitim Bakanlığı Okul Dışı Öğrenme Ortamları K1lavuzu. Ankara.

OECD (2017), PISA 2015 Results (Volume III): Students' Well-Being, PISA, OECD Publishing, Paris. doi: 10.1787/9789264273856-en.

OECD. (2018). Children \& Young People's Mental Health in the Digital Age Shaping the Future. OECD Publishing, Paris.

Okur Berberoğlu, E., Uygun, S. (2013). Examining of outdoor education development in the World and in Turkey, Mersin Üniversitesi Eğitim Fakültesi Dergisi, 9 (2), 32-42.

Özkan, İ. (2009). The travel- observation and analysis method on student achievement about the sources of our country unit in 6th grade social studies curriculum (Unpublished master's thesis). Abant İzzet Baysal Üniversitesi/Sosyal Bilimler Enstitüsü: Bolu.

Özür, N. (2010). Effect of non-classroom based learning in social studies course on student success. (Unpublished doctoral thesis). Gazi Üniversitesi/Eğitim Bilimleri Enstitüsü, Ankara.

Pew Research Center (2018), Teens, Social Media \& Technology 2018, Retrieved from http://assets.pewresearch.org/wpcontent/uploads/sites/14/2018/05/31102617/PI_2018.05.31_TeensTech_FINAL.pdf.

Priest, S. (1986). Redefining outdoor education: A matter of many relationships. Journal of Environmental Education, 17 (3), 13-15.

Priest, S. (1988). Outdoor leadership around the world: A matter of semantics. Journal of Adventure Education, 5 (1), 9-12.

Prince, H., E. (2018). Changes in outdoor learning in primary schools in England, 1995 and 2017: lessons for good practice, Journal of Adventure Education and Outdoor Learning, doi: 10.1080/14729679.2018.1548363. 
Prisk, C., \& Cusworth, H. (2018). From muddy hands and dirty faces to higher grades and happy places. Outdoor Classroom Day.

Prouty, D., Panicucci, J., \& Collinson, R. (2007). Adventure education: Theory and applications. Champaign, IL. Human Kinetics.

Saraç, H. (2017). Researches related to outdoor learning environments in Turkey: Content analysis study. Ë̆itim Kuram ve Uygulama Araştırmaları Dergisi, 3 (2), 60-81.

Selanik Ay, T. (2016). Sosyal Bilgiler Öğretiminde Sınıf Dışı Etkinlikler. Şimşek, S. (Ed.), In Sosyal Bilgiler ve Sinı Öğretmenleri İçin Sosyal Bilgiler Öğretimi, (s. 337-363). Ankara: Anı Yayıncilik.

Şimşek, A., Kaymakçı, S. (2015). Okul Dışı Sosyal Bilgiler Öğretiminin Amacı ve Kapsamı. Ahmet Şimşek ve Selahattin Kaymakçı (Ed.). In Okul Dışı Sosyal Bilgiler Öğretimi, (s. 111). Ankara: Pegem Akademi.

Smith, R. A. L., Walsh, K. M. (2018). Some things in life can't be googled:A narrative synthesis of three key questions in outdoor education. Journal of Youth Studies, 22 (3), 312-329, doi: 10.1080/13676261.2018.1506096.

Sobel, D. (2004). Place-based education. Connecting Classrooms \& Communities, Great Barrington, MA: The Orion Society.

Sözer, Y. ve Oral, B. (2016). Supplementary active outdoor learning process for classroom learning: A meta-synthesis study. International Journal Of Eurasia Social Sciences, 7 (22), 278-310.

Stoecklin, V. L. (2009). My summers at Beanstalk Children's garden. Gardening with Children, 80-84.

Taşoğlu, M. (2010). Activities outside school teaching geography of the student's academic effects of success (Unpublished master's thesis). Marmara Üniversitesi/Eğitim Bilimleri Enstitüsü, İstanbul.

Tokcan, H. (2015). Okul Dış1 Sosyal Bilgiler Öğretimi ve Öğrenme Teorileri. Şimşek, A. ve Kaymakçı, S. (Ed.). In Okul Dışı Sosyal Bilgiler Öğretimi, (s. 15-40). Ankara: Pegem Akademi.

UNICEF. (2017). The State of the World's Children 2017: Children in a Digital World. NY: UNICEF, New York.

Unilever, (2016). President Richard Edelman, Dirt is Good: The Campaign For Play. Retrived from https://www.edelman.co.uk/insights/dirt-good-campaign-play.

Yazıcı, T., Çobanoğlu, O., E. (2017). Education and historical origins of outdoor in Turkey, Uluslararası Türk Eğitim Bilimleri Dergisi, 5 (9), 385-401.

\section{Biographical Statements}

Görkem AVCI has a Ph.D in the Department of Primary Education at the University of Dokuz Eylül. Now he studies working at the Department of Social Sciences Education at University of Bartın. He studies on primary education, social sciences and geography education.

Nevzat GÜMÜŞ is a Professor in the Department of Social Sciences Education at the University of Dokuz Eylül. He studies on geography education, social sciences education and teacher preparation. 